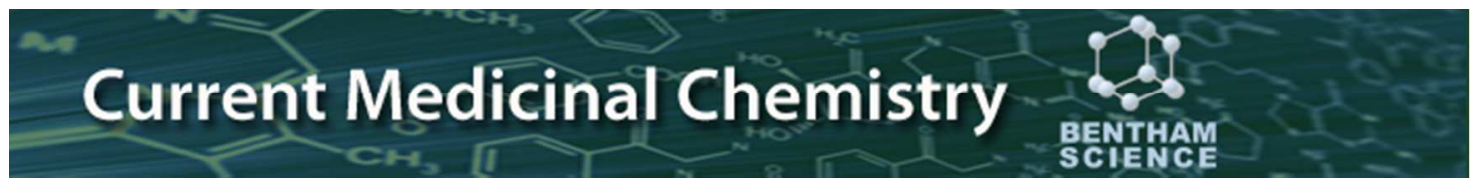

\title{
Kynurenines and PACAP in migraine: medicinal chemistry and pathogenetic aspects
}

\begin{tabular}{|c|c|}
\hline Journal: & Current Medicinal Chemistry \\
\hline Manuscript ID & CMC-2016-0496.R1 \\
\hline Manuscript Type: & Review \\
\hline Date Submitted by the Author: & $n / a$ \\
\hline Complete List of Authors: & $\begin{array}{l}\text { Tajti, János; Szegedi Tudomanyegyetem, Department of Neurology } \\
\text { Szok, Délia; Szegedi Tudomanyegyetem, Department of Neurology } \\
\text { Nagy-Grócz, Gábor; Szegedi Tudomanyegyetem, Faculty of Health } \\
\text { Sciences and Social Studies; Szegedi Tudomanyegyetem, MTA-SZTE } \\
\text { Neuroscience Research Group } \\
\text { Tuka, Bernadett; Szegedi Tudomanyegyetem, MTA-SZTE Neuroscience } \\
\text { Research Group } \\
\text { Petrovics-Balog, Anna; Szegedi Tudomanyegyetem, Department of } \\
\text { Neurology } \\
\text { Toldi, József; University of Szeged, Department of Physiology, Anatomy } \\
\text { and Neuroscience; MTA-SZTE Neuroscience Research Group of the } \\
\text { Hungarian Academy of Sciences and University of Szeged } \\
\text { Vécsei, László; University of Szeged, Department of Neurology; MTA-SZTE } \\
\text { Neuroscience Research Group of the Hungarian Academy of Sciences and } \\
\text { University of Szeged }\end{array}$ \\
\hline Keywords: & $\begin{array}{l}\text { glutamate, kynurenine, migraine, mode of action, pathomechanism, } \\
\text { pituitary adenylate cyclase-activating polypeptide }\end{array}$ \\
\hline \multicolumn{2}{|c|}{$\begin{array}{l}\text { Note: The following files were submitted by the author for peer review, but cannot be converted to } \\
\text { PDF. You must view these files (e.g. movies) online. }\end{array}$} \\
\hline Fig.1.Vecsei..cdx & \\
\hline
\end{tabular}




\section{Kynurenines and PACAP in migraine: medicinal chemistry and pathogenetic aspects}

János Tajti ${ }^{1}$, Délia Szok ${ }^{1}$, Gábor Nagy-Grócz ${ }^{2,3}$, Bernadett Tuka ${ }^{1,2}$, Anna Petrovics-Balog ${ }^{1}$, József Toldi ${ }^{4}$, László Vécsei*1,2

${ }^{1}$ Department of Neurology, Faculty of Medicine, Albert Szent-Györgyi Clinical Center, University of Szeged, Semmelweis u. 6., H-6725, Szeged, Hungary

${ }^{2}$ MTA-SZTE Neuroscience Research Group, Semmelweis u. 6., H-6725, Szeged, Hungary

${ }^{3}$ Faculty of Health Sciences and Social Studies, University of Szeged, Temesvári krt. 31., H6726, Szeged, Hungary

${ }^{4}$ Department of Physiology, Anatomy and Neuroscience, Faculty of Science and Informatics, University of Szeged, Közép fasor 52., H-6726, Szeged, Hungary

*Corresponding author:

László Vécsei

E-mail: vecsei.laszlo@med.u-szeged.hu

Tel.: +3662545348

FAX: +3662545597 


\section{Abstract}

Background: Migraine is a highly disabling neurovascular primary headache disorder, with its exact pathomechanism being still unrevealed. The current leading hypotheses are based on the sensitization and activation of the trigeminovascular system.

Objective: To review the literature with focus on the effects of kynurenines (L-kynurenine and kynurenic acid) and pituitary adenylate cyclase-activating polypeptide on the regulation of the trigeminovascular system.

Method: A literature search was conducted to identify preclinical and clinical publications (198 references) by using the keywords 'kynurenines', 'pituitary adenylate cyclaseactivating polypeptide', and 'migraine' in the database of MEDLINE/PubMed up to 10 September 2016for topical review. Additional filters used included 'review', 'systematic review', 'original article', and 'English language'.

Results: L-kynurenine and kynurenic acid act on the glutamatergic system at the level of the second-order nociceptive neurons in the trigeminal nucleus caudalis. Pituitary adenylate cyclase-activating polypeptide is released from the peripheral nerve endings of the trigeminal pseudounipolar neurons and causes vasodilation and mast cell degranulation, leading to consequent peripheral sensitization of the dural nociceptors. Centrally released pituitary adenylate cyclase-activating polypeptide in the trigeminal nucleus caudalis results in the central sensitization of the second-order neurons. The sensitization process leads to the characteristic features of migraine.

Conclusion: L-kynurenine, kynurenic acid, and pituitary adenylate cyclase-activating polypeptide may have fundamental roles in the initiation of migraine headache attacks. 
Graphical abstract

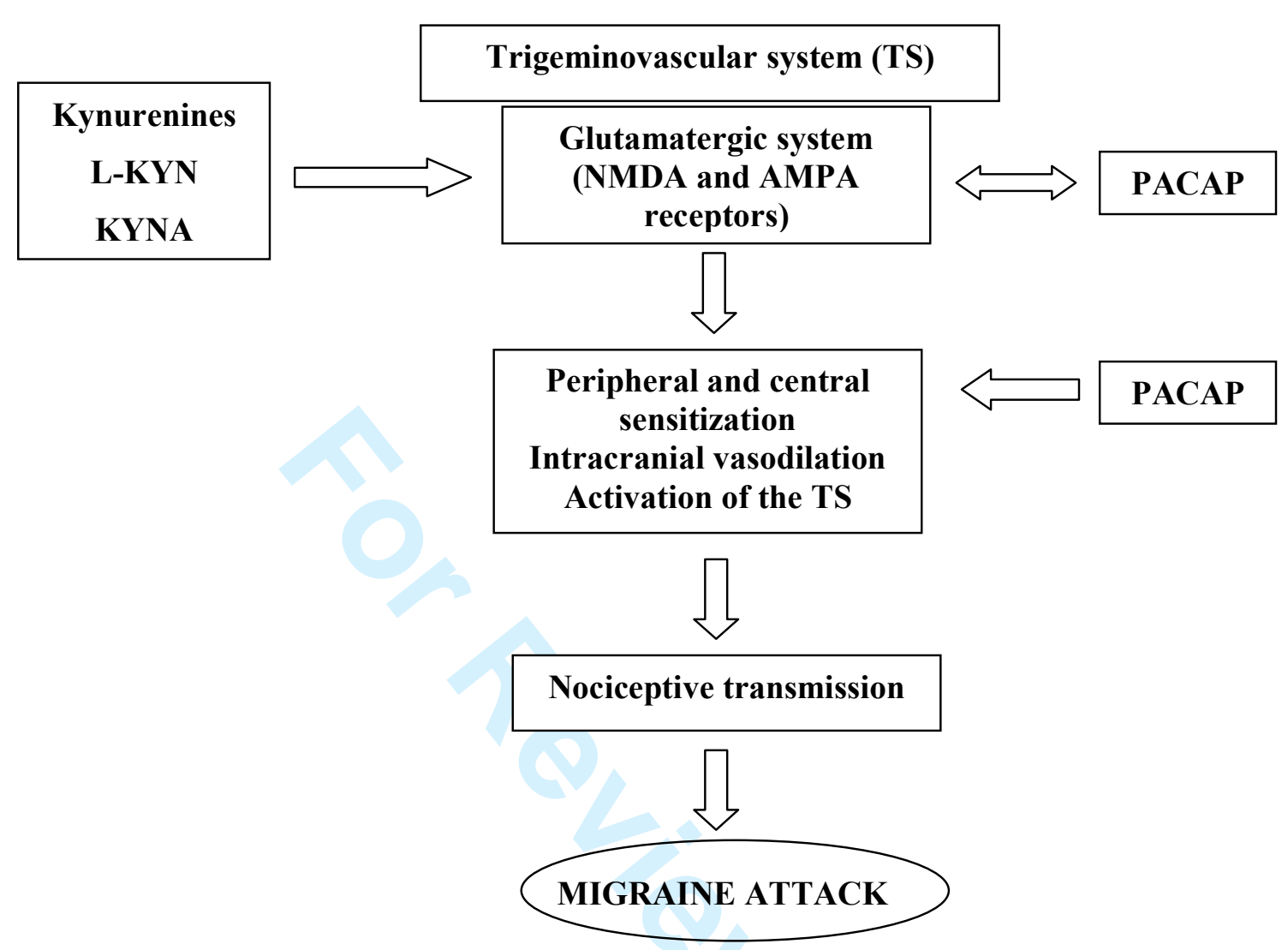

Abbreviations: AMPA: $\alpha$-amino-3-hydroxy-5-methyl-4-isoxazolepropionic acid, KYNA: kynurenic acid, L-KYN: L-kynurenine, NMDA: $N$-methyl-D-aspartate, PACAP: pituitary adenylate cyclase-activating polypeptide, TS: trigeminovascular system

Keywords: glutamate, kynurenine, migraine, mode of action, pathomechanism, pituitary adenylate cyclase-activating polypeptide. 


\section{Introduction}

Migraine as a neurovascular primary headache disorder is ranked the third most common disease worldwide [1]. On the basis of the latest classification of the International Headache Society, migraine can be divided into episodic (with and without aura) and chronic forms [2]. The typical features of a migraine attack include the unilateral location, pulsating quality, moderate or severe intensity, aggravation by routine physical activity, and association with nausea and/or photophobia and phonophobia [2]. Migraine is a disabling disease, having high socio-economic and personal impacts [3-9].

The exact pathomechanism of migraine is still unrevealed. The proposed pathogeneses of the initiation and maintenance of a migraine attack include neuro-vascular alterations, neuropeptide release, neurogenic inflammation, plasma protein extravasation, peripheral and central sensitization, cortical spreading depression (CSD), brain energy deficit, and lesions in the cerebral white matter [10-14]. The trigeminovascular system (TS) provides an important pain transmission link between the vascular andneuronal elements [15, 16].

The TS includes the primary sensory pseudounipolar neurons, the cell bodies of which are located in the trigeminal ganglion (TRIG). Their peripheral branches innervate the cranial vessels and meningeal tissues, whereas their central fibers project to the area of the secondorder neurons within the trigeminal nucleus caudalis (TNC) in the brainstem. The information is conveyed to the somatosensory cortex via the third-order neurons located in the thalamus $[13,14]$.

The coupling mechanism in the TNC is controlled by descending pathways from distinct brainstem nuclei, e.g., the periaqueductal grey matter (PAG), the nucleus raphe magnus (NRM), the dorsal raphe nucleus (DRN), and the locus coeruleus (LC), collectively referred to as the migraine generators $[14,17]$.

It has recently been suggested that glutamate, kynurenines, and pituitary adenylate cyclaseactivating polypeptide (PACAP) may play fundamental roles in the initiation and chronification of migraine headache attacks [18, 19].

Glutamate plays a pivotal role in neurotransmission, and emerging human and animal data suggest that it is crucial in the pathomechanism of migraine. Indeed, elevated levels of glutamate were detected in the plasma, platelets, and cerebrospinal fluid in migraine patients long after the attacks, supporting the hypothesis of a sustained hyperexcitability in the disease [20-22]. It is worthy of note that several genetic polymorphisms that affect glutamatergic neurotransmission have been described in migraineurs $[23,24]$. It is also important to note 
that glutamate receptor antagonists can terminate the aura in patients with familial hemiplegic migraine [25]. Monosodium glutamate is a naturally appearing form of glutamic acid and is able to mimic headache in healthy young volunteers and in rats, an effect mediated by the activation of peripheral $N$-methyl-D-aspartate (NMDA) receptors and dural vasodilation. Data from the literature demonstrate that glutamate has a prominent role in processes important in migraine generation, such as CSD and the activation and sensitization of the trigeminal system, and it is also present in the migraine generators [26-28]. Taken together, it seems clear that the role of glutamate is relevant in the pathomechanism of migraine, and its antagonists may have a therapeutic potential.

Kynurenines are less widely known but highly important products of tryptophan (Trp) metabolism [29]. L-kynurenine (L-KYN) and kynurenic acid (KYNA) have neuroprotective effects, whereas 3-hydroxykynurenine (3-HK), 3-hydroxyanthranilic acid (3-HA), and quinolinic acid (QIUN) have neurotoxic properties [18, 29]. KYNA is one of the endogenous glutamate receptor antagonists. Preclinical data revealed that L-KYN or synthetic analogues of KYNA can dramatically inhibit the activation of second-order neurons in the TNC in animal models of migraine with electrically or chemically stimulated TS [30-33]. Furthermore, L-KYN and KYNA can block the process of CSD in experimental conditions [34, 35]. In recent years, clinical studies have demonstrated multiple alterations in the levels of different kynurenine pathway metabolites (e.g., a reduction in the level of L-KYN and an increased level of anthranilic acid (ANA)) in the serum of chronic migraine patients [36].

PACAP is a member of the vasoactive intestinal peptide (VIP)/secretin/glucagon neuropeptide family and exists in two biologically active forms: PACAP1-27 and PACAP138[37]. The presence of PACAP in human TRIG and TNC has been demonstrated [38, 39]. The importance of PACAP in migraine has first been pointed out by clinical studies [40]. Intravenous administration of PACAP1-38 provoked migraine-like attacks accompanied by vasodilation in migraine patients [40, 41]. Experimental data revealed the effect of PACAP on the TS in migraine animal models as well $[42,43]$. In line with these, alterations in plasma PACAP1-38 concentration have been demonstrated in migraineurs both ictally and interictally [44].

This paper gives an overview of the currently available data as regards the contribution of the kynurenine pathway and PACAP in the pathogenesis of migraine, with special focus on potential therapeutic implications. 


\section{Kynurenines}

Chemistry of the kynurenine pathway

Trp is an essential amino acid, playing a crucial role in the synthesis of serotonin, melatonin, tryptamine, and L-KYN ((S)-2-amino-4-(2-aminophenyl)-4-oxobutonic acid). The major branch of Trp metabolism is the kynurenine pathway, producing neuroactive compounds and nicotinamide adenine dinucleotide $\left(\mathrm{NAD}^{+}\right)$(Figure 1).

The initial and rate-limiting step in the kynurenine pathway is linked to three iron-dependent enzymes, indolamine 2,3-dioxygenase 1 and 2 (IDO1 and IDO2), and tryptophan 2,3dioxygenase (TDO). IDO was recognized in 1957 as a heme protein. The enzyme can be activated by interferon- $\gamma$ (IFN- $\gamma$ ) and is present in the central nervous system (CNS), whereas TDO occurs primarily in peripheral tissues, especially in the liver. IDO and TDO convert Trp to $\mathrm{N}$-formyl-L-kynurenine by opening the Trp ring in a reaction which produces peroxides and highly reactive oxygen and hydroxyl radicals [45-48]. $N$-formyl-L-kynurenine is then further degraded by formamidase to form L-KYN. Limited data are available about the biological activity of $N$-formyl-L-kynurenine, owing to its rapid degradation.

L-KYN has antioxidant properties and can cross the blood-brain barrier. Some $60 \%$ of LKYN present in the CNS is taken up from the blood. L-KYN was demonstrated to be an endogenous ligand of the aryl-hydrocarbon receptor, which has important roles in the immune response and tumor genesis [48-52]. L-KYN can be metabolized via three different pathways. The first branch of the kynurenine pathway transforms L-KYN to ANA by kynureninase (Lkynurenine hydrolase). ANA is supposed to have an anti-inflammatory effect via forming a complex with copper and inactivating hydroxyl radicals [53]. ANA is further metabolized to 3-HA by 3-hydroxy-anthranilic acid 3,4-dioxygenase (3-HAO), an iron-dependent enzyme. 3HAO requires oxygen and sulfhydryl groups for its activation and it is predominantly present in astrocytes within the CNS $[54,55]$.

The second branch of the kynurenine pathway starts with the hydroxylation of L-KYN at the third position by the flavin-dependent kynurenine 3-monooxygenase (KMO) to yield 3-HK. 3-HK can be further converted to xanthurenic acid (XA) and 3-HA. 3-HK and 3-HA can increase the level of oxidative stress via the production of free radicals, leading to neuronal damage [56]. Moreover, these molecules can cause excitotoxicity and cell death in neuronal cell cultures [57, 58]. However, ANA is also able to transform into 3-HA, which further transforms into QUIN (pyridine-2,3-dicarboxylic acid). QUIN is an agonist of the NMDA 
receptors and can cause neuronal death when administered intrastriatally [57]. It also provokes lipid peroxidation and generates reactive oxygen species [59]. QUIN is then converted to $\mathrm{NAD}^{+}$in the final step of this branch of the kynurenine pathway [60].

The last branch of the pathway starts with the modification of L-KYN to yield KYNA (4hydroxi-1H-quinoline-2-carboxylic acid) by kynurenine aminotransferases (KAT)s, which have 4 subtypes with different biochemical profiles [61]. KATs belong to the group of pyridoxal 5-phosphate (PLP)-dependent enzyme family. PLP is connected covalently to the lysine residue of KATs by a Schiff base transaldimine link.

KAT I (glutamine transaminase K or cysteine conjugate beta-lyase) is present in neurons and asytrocytes [62, 63]. KAT II (alpha-aminoadipate aminotransferase) was isolated from rat kidney [64]. Under physiological conditions, KATI and KAT II are proposed to be responsible for the majority of KYNA production in mammalians [61, 63].

The more recently discovered KATs include KAT III (cysteine conjugate beta-lyase 2), which is present in the kidney, the heart, the liver, and the neuroendocrine tissues, and KAT IV (glutamic-oxaloacetic transaminase 2 or mitochondrial aspartate aminotransferase).

In contrast with QUIN, KYNA has a neuroprotective effect and can mitigate neuronal damage in excitotoxicity and ischemia $[65,66]$.

KYNA was discovered by Justus von Liebig in 1853 in urine, and half a century later, the substance was recognized as a bioproduct of Trp metabolism. KYNA is an endogenous metabolite of the kynurenine pathway and behaves as an antagonist at the strychnineinsensitive glycine-binding site and, at higher doses, at the NMDA recognition site [67]. In addition, KYNA exerts mild antagonistic effects on kainate- and $\alpha$-amino-3-hydroxy-5methyl-4-isoxazolepropionic acid (AMPA)-sensitive glutamate receptors. Furthermore, it is of note that the effect of KYNA on AMPA receptor-mediated action is facilitatory at low concentrations (nanomolar-micromolar) and inhibitory at high concentrations (micromolarmillimolar) [68, 69]. A line of evidence suggested that KYNA is an antagonist at the $\alpha 7$ nicotinic acetylcholine receptor, thereby decreasing the presynaptic release of glutamate; however, this theory has recently been questioned [70, 71]. In addition, KYNA influences the G protein-coupled receptor 35 (GPR35) and may provoke the generation of inositol trisphosphate, promoting $\mathrm{Ca}^{2+}$ mobilization. KYNA is present both in the central and peripheral tissues in low concentrations $(10-150 \mathrm{nM})$, and is generated in the CNS predominantly by glial cells $[54,72]$. 
Furthermore, it is worthy of note that KYNA is not the only kynurenine metabolite to have positive neuromodulatory effects: L-KYN, ANA, and XA can induce analgesia in the different types of experimental pain models [73].

Therapeutic limitations of KYNA and possible chemical solutions

The main limitation of the widespread use of KYNA is its poor ability to cross the bloodbrain barrier. To overcome this problem, one possibility is to use the precursor of KYNA, LKYN, or its halogenated derivatives. Data from animal studies showed that L-KYN has neuroprotective and antinociceptive effects, and its halogenated derivatives, 4,6dicholorokynurenine and 4-chlorokynurenine are able to transform into halogenated KYNA derivatives (5,7-dichlorokynurenic acid and 7-chlorokynurenic acid, respectively), which have increased affinity to the glycine-binding site of NMDA receptors [33, 74, 75]. Another possibility is to develop KYNA analogues with improved ability to cross the blood-brain barrier. New KYNA analogues have a promising therapeutic potential in the treatment of headache as well neurodegenerative disorders [76]. Recently, our research group have created KYNA analogues, including( $N$-(2- $N, N$-dimethylaminoethyl)-4-oxo-1H-quinoline-2carboxamide hydrochloride (KA1) and $N$-(2- $N$-pyrrolidinylethyl)-4-oxo-1H-quinoline-2carboxamide hydrochloride (KA2), which successfully inhibited the trigeminal activation and sensitization in animal models of migraine [77, 78]. A third option is shifting the kynurenine pathway towards the production of KYNA by the use of specific enzyme inhibitors of kynureninase and $\mathrm{KMO}$, the latter being the most comprehensively examined enzyme inhibitor of the pathway, since their inhibition prevents the production of neurotoxic kynurenines, such has 3-HK and QUIN. Supporting this concept, a wealth of animal data confirms that the inhibition of KMO is able to increase the level of KYNA and decrease that of 3-HK and QUIN [79, 80]. The administration of the KMO inhibitor, (R,S)-3,4dichlorobenzoylalanine (FCE28833A), was effective in increasing KYNA and L-KYN concentrations in the rat brain[81]. Representatives from another group of KMO inhibitors, N(4-phenylthiazol-2-yl)benzenesulfonamides, were likewise able to raise the level of KYNA in the extracellular hippocampal fluid [82].

Experimental data with KYNA and its analogues: preclinical and clinical implications

Numerous studies indicate that KYNA and its analogues have antinociceptive effects at the level of both the first- and the second-order sensory neurons [83]. KYNA is capable of 
attenuating the activation of migraine generators and decreasing mechanical allodynia and pain sensitivity in the tail-flick and the hot-plate tests [84-86].

Systemic administration of nitroglycerin (NTG) is one of the human and animal models of migraine, resulting in the activation and sensitization of the trigeminal system. Pretreatment with L-KYN together with probenecid (PROB; an inhibitor of KYNA excretion) or that with KYNA analogues, KA1 or KA2, attenuated the NTG-induced behavioral changes in the rat as well as morphological alterations in the TNC, probably by the inhibition of NMDA receptors $[32,33,78]$. In a recent study, it has been shown that NTG decreased the expression of KAT II, an enzyme converting L-KYN to KYNA, probably implicating decreased KYNA levels as well[87].

Another experimental setting takes advantage of the electrical stimulation of the TRIG, which also results in decreased KAT immunoreactivity in mast cells, Schwann cells, and dural macrophages [88].

Several studies have shown that there is a connection between the kynurenines and the CSD. CSD is a self-propagating process, the electrophysiological correlate of migraine aura, and is able to activate the trigeminal system in experimental animals [89, 90]. L-KYN and KYNA suppressed CSD in a $\mathrm{KCl}$-induced model [34, 35].

Another model of the trigeminal activation and sensitization takes advantage of the Complete Freund's Adjuvant (CFA)-induced dural inflammation. In this model, a KYNA analogue was able to abolish the CFA-generated inflammatory response [91].

To examine trigeminal inflammation and nociception, the orofacial formalin test can also be used, as a stable model for the investigation of somatic pain involving the activation and sensitization of the trigeminal system [92]. In this model, PROB exerted an antinociceptive effect in rats [93]. Notably, PROB is able to increase the concentration of KYNA by inhibiting its excretion in the nervous system, which may contribute to the observed antinociceptive effect [94]. In a most recent study, the effects of two KYNA analogues, KA1 and KA2, were tested in the orofacial formalin model, revealing that the two analogues were able to inhibit the formalin-induced behavioral and morphological changes and increased the concentration of KYNA [95].

Although the exact mechanism of action of KYNA and its analogues remains unknown, some pieces of the puzzle are starting to fall into place. KYNA can exert its effect both in the periphery and in the CNS. In the periphery, KYNA acts on the glutamate receptors, especially NMDA receptors, localized on certain components of the peripheral nervous system, 
including the trigeminal and dorsal root ganglion, Schwann cells, and the primary sensory afferents [96-99]. As mentioned above, KYNA also has an effect on the GPR35 receptor, which is present in the nociceptive pathway, for example in the dorsal root ganglion; therefore, KYNA may exert its peripheral effect in part on this receptor [100].

In addition to a peripheral action, KYNA and its analogues have a modulatory potential on second-order neurons as well. KYNA was effective in providing analgesia in the tail-flick, hot-plate, and orofacial formalin tests in mice and rats, as mentioned above. These results are in line with animal studies reporting that kynurenine metabolites can influence pain sensation at the level of the spinal cord [84]. When administered into the spinal cord of cats, KYNA was effective in decreasing the muscular and cutaneous nociceptive reaction of wide dynamic range neurons [101]. In rats, KYNA and its analogues were able to prevent the NTG- or CFAinduced activation and sensitization of the trigeminal system in the TNC, where the trigeminal second-order nociceptive neurons are located [32, 33, 78, 91]. Therefore, KYNA and its derivatives can influence the second-order neurons in the trigeminal system.

There is a number of experimental data suggesting that kynurenines influence the activity of migraine generators, including the NRM, the DRN, the LC, and the PAG. Indeed, KYNA can decrease serotonergic responses of the DRN induced by phasic auditory stimulation or the electrical stimulation of the lateral habenula [102, 103]. KYNA can also diminish the activation of the NRM neurons induced by glutamate, and is able to prevent the activation of noradrenergic neurons in the LC provoked by electrical stimulation of the hindpaw of rats $[104,105]$. In addition, the co-administration of KYNA with morphine into the PAG increased the nociceptive effect of morphine [106].

To date, only few clinical data are available as regards kynurenine pathway alterations in migraine. Recent studies by Curto and her colleagues showed altered serum levels of kynurenine metabolites (L-KYN, KYNA) in patients with chronic migraine and cluster headache $[36,107]$. This group was the first to conclude that these two types of primary headaches are both associated with decreased levels of kynurenine metabolites in the peripheral blood.

Summarizing the preclinical and clinical data from the literature, we can conclude that the metabolites of the kynurenine pathway appear to play relevant roles in the pathomechanism of migraine, and they might represent a new potential therapeutic option in the treatment of the disease (Figure 2). 
Link between the kynurenines and the other endogenous systems

Several lines of evidence have been put forth to support the hypothesis that the kynurenine pathway has a strong interaction with other endogenous systems, including the endocannabinoid system. Recently, numerous studies have indicated that changes in the levels of endocannabinoids within the nervous system are associated with nociception and the pathomechanism of migraine [108]. An increased level of KYNA achieved by the use of the KMO inhibitor 3,4-dimethoxy-[-N-4-(nitrophenyl)thiazol-2-yl]-benzenesulfonamide (also known as Ro 61-8048) was capable of reducing the self-administration of $\Delta^{9}$ tetrahydrocannabinol (THC) in squirrel monkeys [109]. In addition, the first discovered endocannabinoid, anandamide, was able to attenuate the NTG-induced decrease in KAT II expression [87].

Another endogenous system influenced by KYNA is the opioid system. The co-administration of KYNA with morphine raised the acute effect of morphine in rats [106]. Furthermore, KYNA and KA1 reduced the opioid and nociceptin receptor-mediated G-protein activity without demonstrating any affinity towards of opioid receptors [106, 110], an indirect effect which can be attributed to a decreased G-protein activity or a diminished expression of opioid receptors [110].

On the other hand, KYNA plays an important role in the regulation of dopaminergic neurotransmission. An increase in the level of KYNA results in the inhibition of dopamine release; therefore, KYNA is able to influence the levels of dopamine [111]. The decreased level of brain KYNA as a result of the inhibition of KAT II was able to cause an elevation in the extracellular levels of dopamine [112]. In addition, alterations in brain KYNA concentration can be associated with cognitive effects. Indeed, administration of KYNA or LKYN to rats caused impairments in visuospatial working memory, sensory gating, and contextual learning, phenomena linked to glutamatergic and dopaminergic neurotransmission [113-115].

It is also important to note that TDO activity is under the control of blood corticosterone levels and the activity of IDO is regulated by steroids [116, 117].

The immune system represents another endogenous system which has a strong connection with kynurenines. IDO has essential roles in immune modulation in relation to processes such as infection, transplantation, autoimmunity, and pregnancy. IDO is an immunosuppressive enzyme, with a number of its products being able to inhibit $\mathrm{T}$ cell proliferation and activate regulatory $\mathrm{T}$ cells; therefore, IDO might have an effect on the negative feedback suppression 
of T cell response [118]. Importantly, a chronic CNS inflammation might cause an increased activity of IDO by an IFN- $\gamma$-mediated process, a phenomenon which might contribute to the pathomechanism of migraine [18]. Notably, not only kynurenines can influence the immune system, but immune molecules such as cytokines can in turn modulate the activity of the kynurenine pathway as well: in particular, tumor necrosis factor- $\alpha$ (TNF- $\alpha$ ) and interleukins (IL)s, IL-1, -2, -4, -13, and -23 have a strong modulatory effect on the activation of IDO [118].

Influencing the kynurenine pathway - chemical and nutritional aspects

Several enzymes of the kynurenine pathway are vitamin-dependent, including KMO, kynureninase, and the KATs [119]. A number of vitamins from the B family can either directly or indirectly upregulate and/or downregulate the activity of the above mentioned enzymes. In particular, vitamin B6 (pyridoxal) has a crucial role in Trp metabolism, being implicated in the physiological function of both the serotonin and kynurenine pathways, and it also functions as a coenzyme of the KATs and kynureninase [120]. These data are in accordance with a recent study demonstrating that the combined application of vitamin B6 and B12 was effective in the reduction of migraine-associated symptoms [121].

On the other hand, it is well-known that pyridoxal can form chelates with monovalent cations, such as $\mathrm{K}^{+}, \mathrm{Li}^{+}$, and $\mathrm{Na}^{+}$, and divalent cations, including $\mathrm{Mg}^{2+}$ and $\mathrm{Ca}^{2+}$ [120]. Metal ions can also catalyze non-enzymatic reactions of amino acids with pyridoxal, influencing the function of PLP enzymes $[122,123]$. As the polar side chain of proteins could interact with metal ions, these ions have an explicit effect on the enzyme function. Increased concentration of $\mathrm{Pb}^{2+}$ and $\mathrm{Zn}^{2+}$ are able to inhibit the activity of kynureninase; besides, $\mathrm{Co}^{2+}$ and $\mathrm{Zn}^{2+}$ can inhibit the activity of both the KATs and kynureninase by the blockage and inactivation of sulfhydryl groups of the enzymes $[124,125]$. These results raise the interesting possibility that influencing the enzymes of the kynurenine pathway by vitamin B6 or cations might have a therapeutic potential.

Recently, a growing attention has been dedicated to the nutritional aspects of kynurenines. Resveratrol (3,5,4'-trihydroxystilbene) is a polyphenol, which can be found in several nutrients, including red wine, peanuts, and cocoa. It has immunomodulatory and anticancer effects $[126,127]$. A recent study has shown that resveratrol intake enhanced the activity of IDO in human volunteers [128]. Though in this study, no significant change was observed in the levels of L-KYN, the possibility cannot be excluded that resveratrol can influence the levels of kynurenine metabolites. Furthermore, one should keep in mind that several types of 
red wine are able to induce migraine attacks. The contribution of the non-flavonoid resveratrol in wine-triggered attacks is suggested to be unlikely, and tannins and phenolic flavonoid components of the wine are generally considered to be responsible for the induction of migraine attacks [129].

\section{PITUITARY ADENYLATE CYCLASE-ACTIVATING POLYPEPTIDE}

Basic biochemical features of PACAP and its receptors

PACAP is a member of the VIP/secretin/glucagon neuropeptide superfamily and is considered to be a 'brain-gut peptide', being widely expressed in the animal and human organisms [37, 130]. PACAP was discovered based on its ability to increase adenylate cyclase activity in rat pituitary cells, and was first isolated from the ovine hypothalamus in 1989 [131]. Genetic studies showed that the human gene of PACAP (ADCYAP1) is localized on the short arm of chromosome 18 (18p11) [132]. The chemical structure of the peptide exists in two biologically active amidated forms, referred to as PACAP1-38 and PACAP1-27, containing 38 and 27 amino acids, respectively (Figure 3). PACAP1-38has been revealed to account for some $90 \%$ of the total PACAP content in mammalian tissues; however, it is rapidly metabolized and its plasma elimination half-life is very short, being less than 5 min [133]. PACAP can be found in the central and peripheral nervous systems, in the endocrine and exocrine glands, e.g., pancreas and gonads, as well as in the urogenital and respiratory systems, thereby it functions as a pleiotropic peptide [134-142]. PACAP has many functions asa hypophysiotropic hormone; furthermore, it also works as a neuromodulator and neurotransmitter within the nervous system [143-147]

In addition, PACAP exerts antiapoptotic, neuroprotective, and differentiation-inducing effects in the developing nervous system [143-148]. In addition, it plays crucial modulatory and protective roles in the reproductive, cardiovascular, gastrointestinal, and respiratory systems [149-155].

The actions of PACAP are mediated via the following three receptors: $\mathrm{VPAC}_{1}$ (formerly designated the VIP, VIP1 or PACAP type II receptor), $\mathrm{VPAC}_{2}$ (known as the VIP2 or PACAP type III receptor), and $\mathrm{PAC}_{1}$ (previously referred to as the PACAP type I receptor). The $\mathrm{PAC}_{1}$ receptor has a 1000-fold higher affinity for PACAP1-27 and PACAP1-38 than for VIP [156-158]. The effect of PACAP on its different receptors induces two substantial signal transduction pathways. Through Gs- or Gq/11-protein activation, a number of kinases exert a 
variety of physiological and pathophysiological effects $[37,156]$. It has been demonstrated that PACAP1-38-induced meningeal vasodilation is realized by the activation of $\mathrm{VPAC}_{2}$ receptors [159]. The investigation of the TS as regards PACAP and the release of calcitonin gene-related peptide (CGRP), a molecule relevant in the pathogenesis of migraine[14], demonstrated that unlike PACAP1-38, maxadilan, a PAC $_{1}$ receptor agonist, had no effect on CGRP release in the $\mathrm{TNC}$, whereasM65, a $\mathrm{PAC}_{1}$ receptor antagonist, failed to inhibit the PACAP 1-38-induced release of CGRP. These together raised the possibility of the functional presence of a yet unidentified receptor of PACAP in the TS [160]. Another experimental study reported that only intracerebroventricular administration of a PAC1 receptor antagonist was able to diminish the activation of the second-order nociceptive neurons in the trigemino-cervical complex during dural stimulation [161].

The functions of PACAP in nociceptive and vasodilation processes have been revealed by many studies [162-170]. Immunohistochemical studies demonstrated the presence of this peptide in the trigeminal system, e.g., TRIG, TNC, and different brainstem nuclei [38, 39, 134, 171, 172]. Immunohistochemical data demonstrated the presence of $\mathbf{P A C}_{1}$ and VPAC $_{2}$ receptors in small-diameter TRIG neurons [173]. Reverse transcriptionpolymerase chain reaction revealed the presence of $\mathrm{VPAC}_{2}$ and several splice variants of the $\mathrm{PAC}_{1}$ receptor in TRIG [173]. There is functional evidence that $\mathrm{VPAC}_{1}$ receptors are lacking in the TRIG of rats [174] (Figure 4). An early study showed that about $68 \%$ of nociceptin-immunopositive cells in the human TRIG contained PACAP [175]. A human tissue study examining the TNC and the cervical 1-cervical $2\left(\mathrm{C}_{1}-\mathrm{C}_{2}\right)$ levels of the spinal cord concluded that the moderately dense CGRP- and PACAP-containing fibers can be detected in the vicinity of numerous substance P (SP)-immunoreactive fibers, but VIPimmunoreactive fibers were not observed [134]. Moreover, PACAP was detected in human parasympathetic otic and sphenopalatine ganglia [176-178]. PACAP1-38 immunoreactivity was found in neurons and satellite glia cells in rat sphenopalatine ganglia [178]. A broad range of data suggests that PACAP functions as an integrator of nociceptive and sensitization processes, besides being involved in neurogenic inflammation [164, 166, 170, 179]. PACAP and glutamate were both detected in the TRIG of rhesus monkeys and rats [180].

Link between PACAP and migraine 
The exact pathomechanism of migraine is unknown, but the activation and sensitization of the TS are among the leading hypotheses [13, 14]. There is a number of evidence highlighting the possible role of PACAP in the pathogenesis of migraine. The first human evidence that demonstrated the significance of PACAP in migraine was published by Schytz et al. in 2009 [40]. Intravenous infusion of PACAP1-38 caused delayed migraine-like attacks, similarly to the effect of nitroglycerin infusion in migraineurs [40, 181, 182]. Moreover, the decrease of the mean blood flow velocity in the middle cerebral artery and the increase of the diameter of the superficial temporal artery were also observed in the PACAP study of migraineurs [40]. After these promising clinical data, preclinical animal studies were performed to explain the background of the effect of PACAP in the human body [42, 43]. After chemical (by nitroglycerin) and electrical (at the TRIG) stimulation of TS, PACAP1-27 and PACAP138immunoreactivity were found significantly increased in TNC in rats. Even more, PACAP138 elevation was found in the plasma after the electrical stimulation of the TRIG in rats [42]. PACAP-deficient mice displayed reduced light-aversive behavior (photophobia), and decreased meningeal blood flow and c-fos expression were detected in the TRIG and TNC relative to wild-type mice after nitroglycerin-induced TS activation [43]. Neurogenic inflammation and mast cell degranulation also take part in the process of migraine [183, 184]. After mast cell degranulation, the released histamine may induce a long-lasting activation of the TS. It has been demonstrated that vasodilation induced by systemically administered PACAP1-38 was diminished in mastocyte-depleted and antihistamine-pretreated rats [185]. PACAP has the capability to release histamine from rat peritoneal or human skin mast cells $[186,187]$. VPAC1 receptor is expressed on mast cells [188]. The importance of mast cell degranulation within the dura is given by its possible association with the activation of peripheral trigeminal fibers, which leads to peripheral sensitization [184, 189, 190]. Electrophysiological studies proved that PACAP1-38 could cause delayed activation and sensitization of second-order neurons in the trigemino-cervical complex, in a process mediated by neuronal $\mathrm{PAC}_{1}$ receptor in rats [161]. Magnetic resonance angiography of selective extra- and intracranial arteries in humans revealed marked and long-lasting dilation of extracranial arteries after PACAP1-38 infusion [41]. Elevated plasma PACAP1-38 immunoreactivity was detected in the spontaneous ictal period compared to the interictal phase of migraineurs [44]. Interestingly, similar data were found in episodic cluster headache patients [191]. However, in tension-type headache patients, interictal plasma PACAP level was unchanged, whereas in the same phase, it was found decreased in migraineurs [192]. A recent clinical study revealed that PACAP mRNA expression in the peripheral blood 
mononuclear cells in migraine patients was significantly reduced compared to tension-type headache, cluster headache, or medication overuse headache patient groups [193]. During the ictal period, PACAP plasma level in the external jugular vein was found elevated, which alteration was reduced 1 hour after treatment with sumatriptan, a potent acute anti migraine drug [194]. In a clinical study, previously genotyped patients with migraine without aura were infused by PACAP1-38, which resulted in delayed migraine-like attacks and elevated plasma levels of VIP, prolactin, S100 calcium binding protein B, and thyroid-stimulating hormone [195]. This finding pointed out that PACAP may activate parasympathetic nerve endings, causing VIP release [195]. However, the presence of the MEF2D gene variant (rs2274316) was not associated with pre-ictal alterations in neuropeptide levels in the plasma, and neither a high family load nor the presence of this risk allele influenced the migraine response to PACAP1-38 infusion [195, 196]. A resting-state functional MRI study demonstrated that intravenously administered PACAP1-38-induced migraine attacks are associated with altered brain network connectivity (in terms of salience, sensorimotor, and default mode networks) [197].

Summary

Theoretically, PACAP may be released from the peripheral and central terminals of the trigeminal nerve endings. Peripherally released PACAP may cause vasodilation and mast cell degranulation, resulting in peripheral sensitization. On the other hand, centrally released PACAP may lead to the activation of second-order sensory neurons in the TNC in a process mediated by the PAC1 receptor, which leads to central sensitization. Both the peripheral and the central sensitization processes take part in the initiation of migraine attacks $[19,184,198$ $201]$.

A possible link between PACAP and kynurenines in pathogenesis of migraine

The glutamatergic system represents a possible link between PACAP and kynurenine pathway as regards the pathomechanism of migraine. Electrophysiological and biochemical clinical studies revealed the presence of cortical hyperexcitability in migraine patients, which pointed to the role of the glutamatergic system in pathomechanism of migraine [20, 202-205]. Experimental data exist suggesting the role of PACAP on the glutamatergic system via its receptors. It has been proposed that 
PACAP may promote the functional coupling between neuronal nitric oxide synthase and NMDA receptors in inflammatory pain processes [179]. Furthermore, a study using the contextual fear conditioning animal model demonstrated that PACAP modulated the consolidation and extinction through NMDA receptors [206]. In the ventromedial nuclei of the hypothalamus, PACAP modulated the NMDA receptor activity via tyrosine phosphorylation by the Src kinase family [207]. In addition to actions on NMDA receptors, PACAP1-38 was shown to regulate the phosphorylation of AMPA receptor in hippocampal cultures [208]. On the basis of the distribution of PACAP and glutamate in the TRIG, immunohistochemical data suggests a possible interaction between the glutamatergic and the CGRP systems [180].

Migraine-related peripheral and central sensitization of the TS is guided by the glutamatergic system, which can be influenced by kynurenines and PACAP. Recent clinical trials in migraine have investigated ionotropic NMDA receptor antagonists (e.g., ketamine and memantine) [209, 210], an ionotropic AMPA receptor antagonists (e.g., BGG492, a.k.a. selurampanel) [211], an ionotropic AMPA/kainate receptor antagonists (LY293558, a.k.a. tezampanel) [212], and a metabotropic glutamate receptor 5 modulator (ADX-10059, a.k.a. raseglurant) [213]. Glutamatergic receptors may serve as novel therapeutic targets in the treatment of migraine.

\section{Conclusion}

Migraine is a neurovascular disorder with an unknown etiopathogenetic background. One of the leading hypotheses is based on the activation and sensitization of the TS. Distinct members of kynurenine system, such as L-KYN and KYNA, as well as the recent hypothetical migraine-related neuropeptide, PACAP, may be connected by their influence on the glutamatergic elements of TS. The activation of excitatory glutamatergic receptors leads to the sensitization of TS. KYNA and its analogues are antagonists of the glutamatergic receptors. PACAP modulates the NMDA and AMPA receptors. Moreover, PACAP exerts its effects on the TS through its receptors $\left(\mathrm{VPAC}_{1}\right.$, $\mathrm{VPAC}_{2}$, and $\mathrm{PAC}_{1}$ ).

As regards future perspectives, KYNA analogues, PAC1 receptor antagonists, and glutamatergic receptor antagonists may provide innovative therapeutic options in migraine headache. 


\section{Acknowledgements}

This work was supported by EUROHEADPAIN (FP7-Health 2013-Innovation; Grant No. 602633), by the MTA-SZTE Neuroscience Research Group of the Hungarian Academy of Sciences and the University of Szeged and by GINOP-2.3.2-15-2016-00034.

We thank Levente Szalárdy for the linguistic correction of the manuscript. 


\section{Tables and figures}
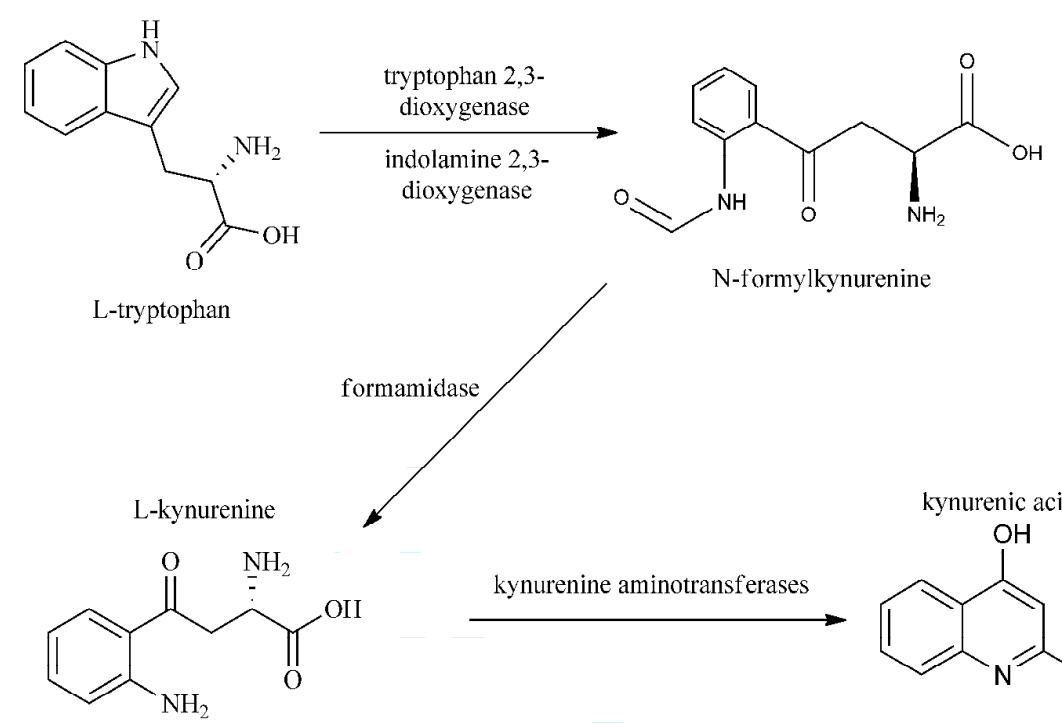

((S-2-amino-4-(2-aminophenyl)-

4-oxobutonic acid)

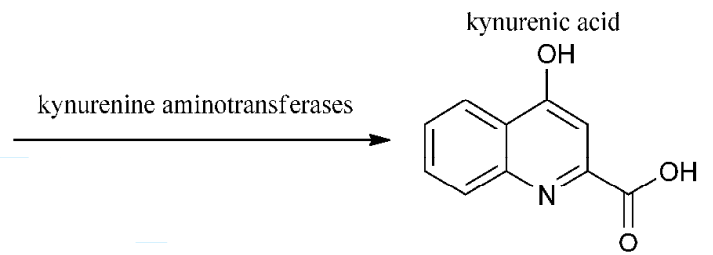

4-hydroxy-1H-quinoline-2carboxylic acid<smiles>Nc1ccccc1C(=O)O</smiles>

2-aminobenzoic acid

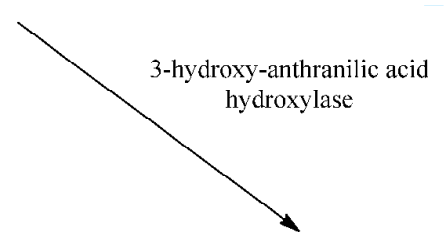

3-hydroxyanthranilic acid<smiles>Nc1c(O)cccc1C(=O)O</smiles>

2-Amino-3-hydroxybenzoic acid

3-hydroxyanthranilic acid 3,4-dioxygenase

quinolinic acid

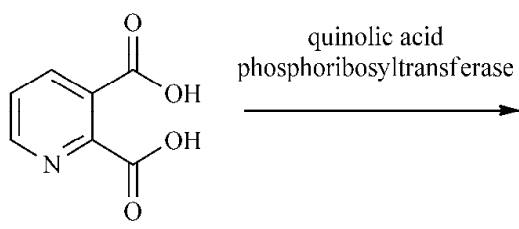

nicotinamide adenine dinucleotid

pyridine-2,3-dicarboxylic acid 
Figure 1. A part of the kynurenine pathway

1

2

3

4

5

6

7

8

9

10

11

12

13

14

15

16

17

18

19

20

21

22

23

24

25

26

27

28

29

30

31

32

33

34

35

36

37

38

39

40

41

42

43

44

45

46

47

48

49

50

51

52

53

54

55

56

57

58

59

60 
1

2

3

4

5

6

7

8

9

10

11

12

13

14

15

16

17

18

19

20

21

22

23

24

25

26

27

28

29

30

31

32

33

34

35

36

37

38

39

40

41

42

43

44

45

46

47

48

49

50

51

52

53

54

55

56

57

58

59

60

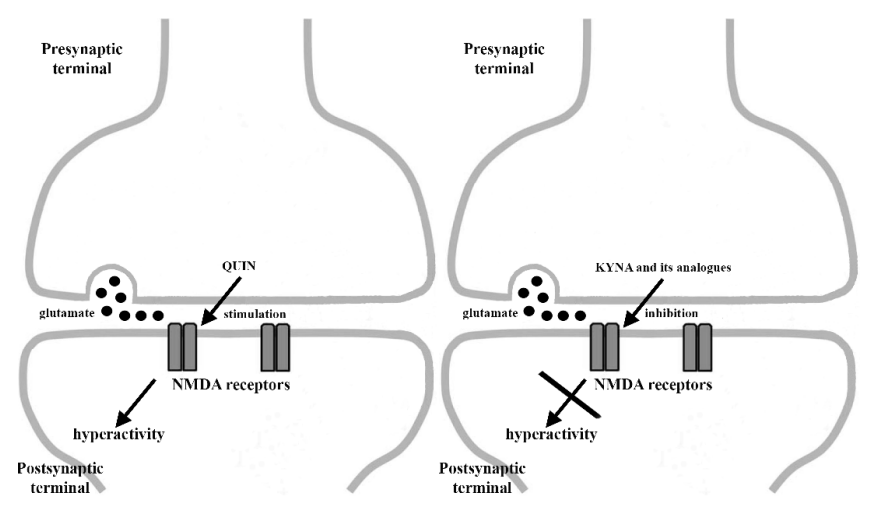

Figure 2. The main action of kynurenic acid and quinolinic acid.

Abbreviations: QUIN: quinolinic acid, KYNA: kynurenic acid, NMDA receptors: N-methylD-aspartate receptors 


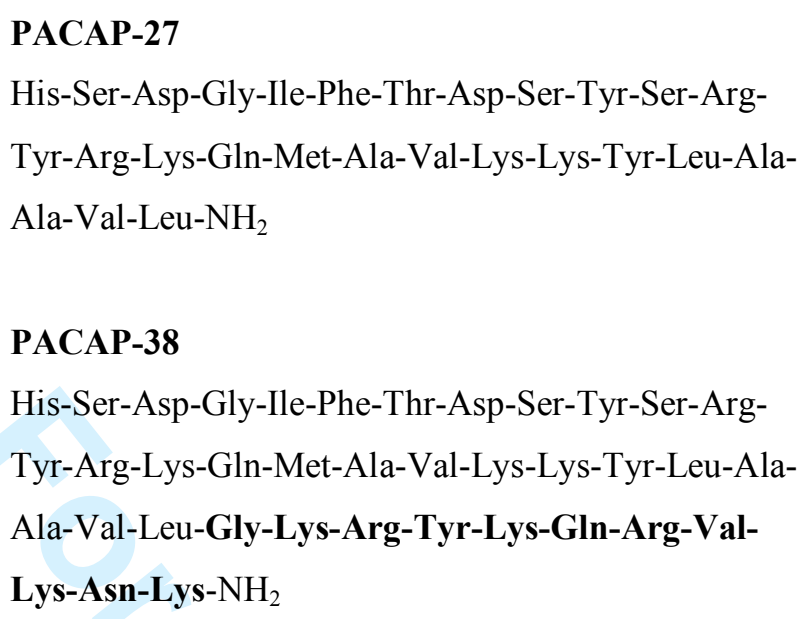

Figure 3. Amino acid sequences of PACAP-27 and PACAP-38 [131] 


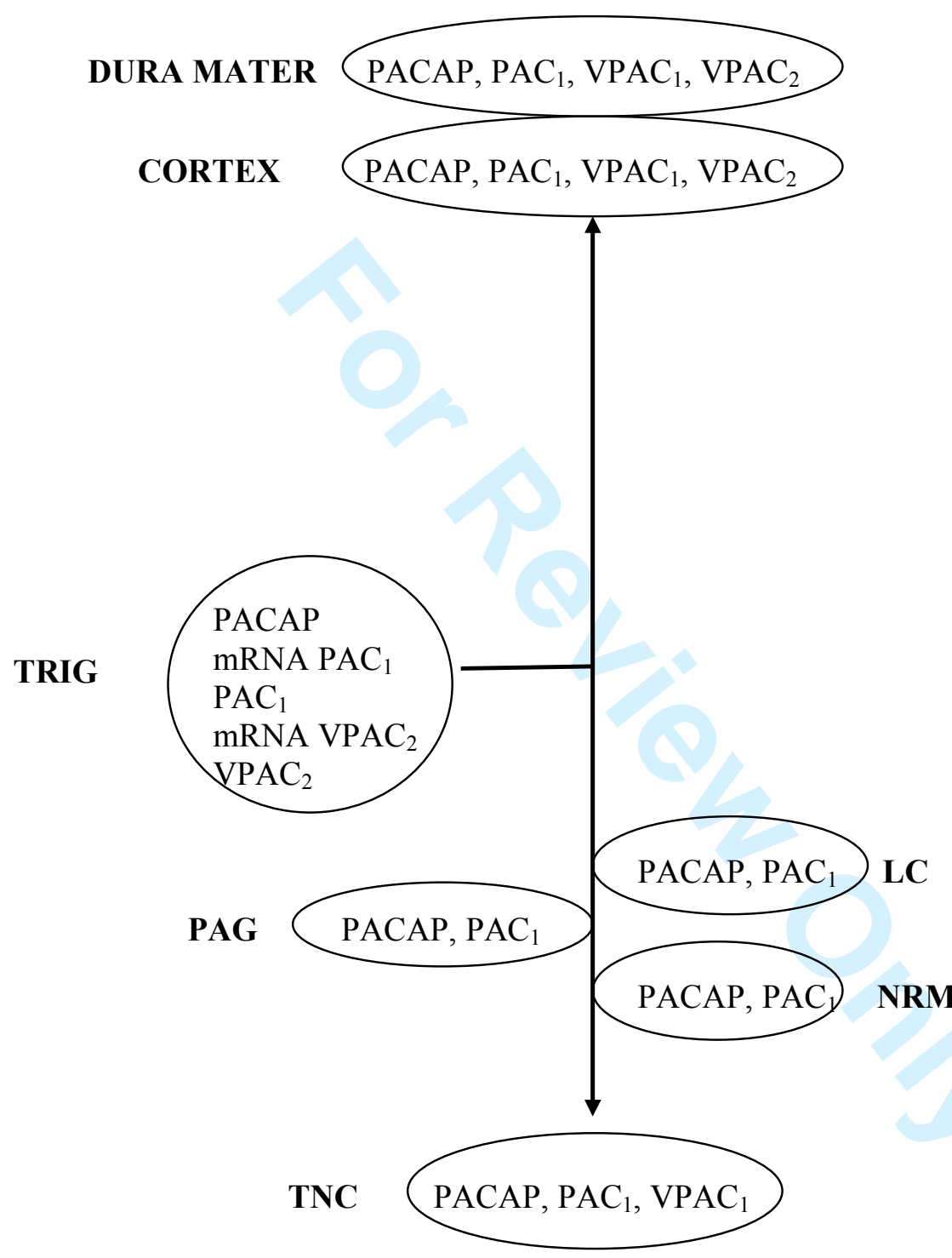

Figure 4. Localization of PACAP and its receptors in the trigeminovascular system

Abbreviations: NRM: nucleus raphe magnus; LC: locus coeruleus; $\mathrm{VPAC}_{1}$ : previously designated as the VIP, VIP1 or PACAP type II receptor, VPAC 2 : known as the VIP2 or PACAP type III receptor; $\mathrm{PAC}_{1}$ : formerly known as the PACAP type I receptor; PACAP: pituitary adenylate cyclase-activating polypeptide; PAG: periaqueductal grey matter; TNC: trigeminal nucleus caudalis; TRIG: trigeminal ganglion [173, 174, 184] 


\section{Figure legends:}

Figure 1. A part of the kynurenine pathway.

Figure 2. KYNA and its analogues are able to inhibit the glutamate-induced hyperexcitability, which has a relevant role in the pathomechanism of migraine.

Figure 3.Amino acid sequences of PACAP-27 and PACAP-38.

Figure 4. PACAP and its receptors are expressed in various parts of the trigeminovascular system. 


\section{References}

[1] Vos, T.; Flaxman, A. D.; Naghavi, M.; Lozano, R.; Michaud, C.; Ezzati, M.; Shibuya, K.; Salomon, J. A.; Abdalla, S.; Aboyans, V.; Abraham, J.; Ackerman, I.; Aggarwal, R.; Ahn, S. Y.; Ali, M. K.; Alvarado, M.; Anderson, H. R.; Anderson, L. M.; Andrews, K. G.; Atkinson, C.; Baddour, L. M.; Bahalim, A. N.; Barker-Collo, S.; Barrero, L. H.; Bartels, D. H.; Basanez, M. G.; Baxter, A.; Bell, M. L.; Benjamin, E. J.; Bennett, D.; Bernabe, E.; Bhalla, K.; Bhandari, B.; Bikbov, B.; Bin Abdulhak, A.; Birbeck, G.; Black, J. A.; Blencowe, H.; Blore, J. D.; Blyth, F.; Bolliger, I.; Bonaventure, A.; Boufous, S.; Bourne, R.; Boussinesq, M.; Braithwaite, T.; Brayne, C.; Bridgett, L.; Brooker, S.; Brooks, P.; Brugha, T. S.; BryanHancock, C.; Bucello, C.; Buchbinder, R.; Buckle, G.; Budke, C. M.; Burch, M.; Burney, P.; Burstein, R.; Calabria, B.; Campbell, B.; Canter, C. E.; Carabin, H.; Carapetis, J.; Carmona, L.; Cella, C.; Charlson, F.; Chen, H.; Cheng, A. T.; Chou, D.; Chugh, S. S.; Coffeng, L. E.; Colan, S. D.; Colquhoun, S.; Colson, K. E.; Condon, J.; Connor, M. D.; Cooper, L. T.; Corriere, M.; Cortinovis, M.; de Vaccaro, K. C.; Couser, W.; Cowie, B. C.; Criqui, M. H.; Cross, M.; Dabhadkar, K. C.; Dahiya, M.; Dahodwala, N.; Damsere-Derry, J.; Danaei, G.; Davis, A.; De Leo, D.; Degenhardt, L.; Dellavalle, R.; Delossantos, A.; Denenberg, J.; Derrett, S.; Des Jarlais, D. C.; Dharmaratne, S. D.; Dherani, M.; Diaz-Torne, C.; Dolk, H.; Dorsey, E. R.; Driscoll, T.; Duber, H.; Ebel, B.; Edmond, K.; Elbaz, A.; Ali, S. E.; Erskine, H.; Erwin, P. J.; Espindola, P.; Ewoigbokhan, S. E.; Farzadfar, F.; Feigin, V.; Felson, D. T.; Ferrari, A.; Ferri, C. P.; Fevre, E. M.; Finucane, M. M.; Flaxman, S.; Flood, L.; Foreman, K.; Forouzanfar, M. H.; Fowkes, F. G.; Franklin, R.; Fransen, M.; Freeman, M. K.; Gabbe, B. J.; Gabriel, S. E.; Gakidou, E.; Ganatra, H. A.; Garcia, B.; Gaspari, F.; Gillum, R. F.; Gmel, G.; Gosselin, R.; Grainger, R.; Groeger, J.; Guillemin, F.; Gunnell, D.; Gupta, R.; Haagsma, J.; Hagan, H.; Halasa, Y. A.; Hall, W.; Haring, D.; Haro, J. M.; Harrison, J. E.; Havmoeller, R.; Hay, R. J.; Higashi, H.; Hill, C.; Hoen, B.; Hoffman, H.; Hotez, P. J.; Hoy, D.; Huang, J. J.; Ibeanusi, S. E.; Jacobsen, K. H.; James, S. L.; Jarvis, D.; Jasrasaria, R.; Jayaraman, S.; Johns, N.; Jonas, J. B.; Karthikeyan, G.; Kassebaum, N.; Kawakami, N.; Keren, A.; Khoo, J. P.; King, C. H.; Knowlton, L. M.; Kobusingye, O.; Koranteng, A.; Krishnamurthi, R.; Lalloo, R.; Laslett, L. L.; Lathlean, T.; Leasher, J. L.; Lee, Y. Y.; Leigh, J.; Lim, S. S.; Limb, E.; Lin, J. K.; Lipnick, M.; Lipshultz, S. E.; Liu, W.; Loane, M.; Ohno, S. L.; Lyons, R.; Ma, J.; Mabweijano, J.; MacIntyre, M. F.; Malekzadeh, R.; Mallinger, L.; Manivannan, S.; Marcenes, W.; March, L.; Margolis, D. J.; Marks, G. B.; Marks, R.; Matsumori, A.; Matzopoulos, R.; Mayosi, B. M.; McAnulty, J. H.; McDermott, M. M.; McGill, N.; McGrath, J.; Medina-Mora, M. E.; Meltzer, M.; Mensah, G. A.; Merriman, T. R.; Meyer, A. C.; Miglioli, V.; Miller, M.; Miller, T. R.; Mitchell, P. B.; Mocumbi, A. O.; Moffitt, T. E.; Mokdad, A. A.; Monasta, L.; Montico, M.; Moradi-Lakeh, M.; Moran, A.; Morawska, L.; Mori, R.; Murdoch, M. E.; Mwaniki, M. K.; Naidoo, K.; Nair, M. N.; Naldi, L.; Narayan, K. M.; Nelson, P. K.; Nelson, R. G.; Nevitt, M. C.; Newton, C. R.; Nolte, S.; Norman, P.; Norman, R.; O'Donnell, M.; O'Hanlon, S.; Olives, C.; Omer, S. B.; Ortblad, K.; Osborne, R.; Ozgediz, D.; Page, A.; Pahari, B.; Pandian, J. D.; Rivero, A. P.; Patten, S. B.; Pearce, N.; Padilla, R. P.; Perez-Ruiz, F.; Perico, N.; Pesudovs, K.; Phillips, D.; Phillips, M. R.; Pierce, K.; Pion, S.; Polanczyk, G. V.; Polinder, S.; Pope, C. A., 3rd; Popova, S.; Porrini, E.; Pourmalek, F.; Prince, M.; Pullan, R. L.; Ramaiah, K. D.; Ranganathan, D.; Razavi, H.; Regan, M.; Rehm, J. T.; Rein, D. B.; Remuzzi, G.; Richardson, K.; Rivara, F. P.; Roberts, T.; Robinson, C.; De Leon, F. R.; Ronfani, L.; Room, R.; Rosenfeld, L. C.; Rushton, L.; Sacco, R. L.; Saha, S.; Sampson, U.; Sanchez-Riera, L.; Sanman, E.; Schwebel, D. C.; Scott, J. G.; Segui-Gomez, M.; Shahraz, S.; Shepard, D. S.; Shin, H.; Shivakoti, R.; Singh, D.; Singh, G. M.; Singh, J. A.; Singleton, J.; Sleet, D. A.; Sliwa, K.; Smith, E.; Smith, J. L.; Stapelberg, N. J.; Steer, A.; Steiner, T.; Stolk, W. A.; Stovner, L. J.; Sudfeld, C.; Syed, S.; Tamburlini, G.; Tavakkoli, M.; Taylor, H. R.; Taylor, J. A.; Taylor, W. J.; Thomas, B.; Thomson, W. M.; Thurston, G. D.; Tleyjeh, I. M.; Tonelli, M.; 
Towbin, J. A.; Truelsen, T.; Tsilimbaris, M. K.; Ubeda, C.; Undurraga, E. A.; van der Werf, M. J.; van Os, J.; Vavilala, M. S.; Venketasubramanian, N.; Wang, M.; Wang, W.; Watt, K.; Weatherall, D. J.; Weinstock, M. A.; Weintraub, R.; Weisskopf, M. G.; Weissman, M. M.; White, R. A.; Whiteford, H.; Wiersma, S. T.; Wilkinson, J. D.; Williams, H. C.; Williams, S. R.; Witt, E.; Wolfe, F.; Woolf, A. D.; Wulf, S.; Yeh, P. H.; Zaidi, A. K.; Zheng, Z. J.; Zonies, D.; Lopez, A. D.; Murray, C. J.; AlMazroa, M. A.; Memish, Z. A., Years lived with disability (YLDs) for 1160 sequelae of 289 diseases and injuries 1990-2010: a systematic analysis for the Global Burden of Disease Study 2010. Lancet 2012,380 (9859), 2163-96.

[2] Headache Classification Committee of the International Headache, S., The International Classification of Headache Disorders, 3rd edition (beta version). Cephalalgia 2013,33 (9), 629-808.

[3] Lipton, R. B.; Stewart, W. F.; Goadsby, P. J., Headache-related disability in the management of migraine. Neurology 2001,56 (6 Suppl 1), S1-3.

[4] Stovner, L.; Hagen, K.; Jensen, R.; Katsarava, Z.; Lipton, R.; Scher, A.; Steiner, T.; Zwart, J. A., The global burden of headache: a documentation of headache prevalence and disability worldwide. Cephalalgia 2007,27 (3), 193-210.

[5] Menken, M.; Munsat, T. L.; Toole, J. F., The global burden of disease study: implications for neurology. Arch Neurol 2000,57 (3), 418-20.

[6] Steiner, T. J.; Scher, A. I.; Stewart, W. F.; Kolodner, K.; Liberman, J.; Lipton, R. B., The prevalence and disability burden of adult migraine in England and their relationships to age, gender and ethnicity. Cephalalgia 2003,23 (7), 519-27.

[7] Leonardi, M.; Steiner, T. J.; Scher, A. T.; Lipton, R. B., The global burden of migraine: measuring disability in headache disorders with WHO's Classification of Functioning, Disability and Health (ICF). J Headache Pain 2005,6 (6), 429-40.

[8] Fishman, P.; Black, L., Indirect costs of migraine in a managed care population. Cephalalgia 1999,19 (1), 50-7; discussion 1.

[9] Gerth, W. C.; Carides, G. W.; Dasbach, E. J.; Visser, W. H.; Santanello, N. C., The multinational impact of migraine symptoms on healthcare utilisation and work loss. Pharmacoeconomics 2001,19 (2), 197-206.

[10] Tajti, J.; Pardutz, A.; Vamos, E.; Tuka, B.; Kuris, A.; Bohar, Z.; Fejes, A.; Toldi, J.; Vecsei, L., Migraine is a neuronal disease. J Neural Transm (Vienna) 2011,118 (4), 511-24.

[11] Tajti, J.; Szok, D.; Pardutz, A.; Tuka, B.; Csati, A.; Kuris, A.; Toldi, J.; Vecsei, L., Where does a migraine attack originate? In the brainstem. J Neural Transm (Vienna) 2012,119(5), 557-68.

[12] Szabo, N.; Kincses, Z. T.; Pardutz, A.; Tajti, J.; Szok, D.; Tuka, B.; Kiraly, A.; Babos, M.; Voros, E.; Bomboi, G.; Orzi, F.; Vecsei, L., White matter microstructural alterations in migraine: a diffusion-weighted MRI study. Pain 2012,153 (3), 651-6.

[13] Pietrobon, D.; Moskowitz, M. A., Pathophysiology of migraine. Annu Rev Physiol 2013,75, 365-91.

[14] Edvinsson, L.; Villalon, C. M.; MaassenVanDenBrink, A., Basic mechanisms of migraine and its acute treatment. Pharmacol Ther 2012,136 (3), 319-33.

[15] Moskowitz, M. A., Trigeminovascular system. Cephalalgia 1992,12 (3), 127.

[16] Goadsby, P. J., Pathophysiology of migraine. Neurol Clin 2009,27 (2), 335-60.

[17] Weiller, C.; May, A.; Limmroth, V.; Juptner, M.; Kaube, H.; Schayck, R. V.; Coenen,

H. H.; Diener, H. C., Brain stem activation in spontaneous human migraine attacks. Nat Med 1995, 1 (7), 658-60.

[18] Vecsei, L.; Szalardy, L.; Fulop, F.; Toldi, J., Kynurenines in the CNS: recent advances and new questions. Nat Rev Drug Discov 2013,12 (1), 64-82.

[19] Vecsei, L.; Tuka, B.; Tajti, J., Role of PACAP in migraine headaches. Brain 2014,137 (Pt 3), 650-1. 
[20] Martinez, F.; Castillo, J.; Rodriguez, J. R.; Leira, R.; Noya, M., Neuroexcitatory amino acid levels in plasma and cerebrospinal fluid during migraine attacks. Cephalalgia 1993,13 (2), 89-93.

[21] Cananzi, A. R.; D'Andrea, G.; Perini, F.; Zamberlan, F.; Welch, K. M., Platelet and plasma levels of glutamate and glutamine in migraine with and without aura. Cephalalgia 1995, 15 (2), 132-5.

[22] D'Eufemia, P.; Finocchiaro, R.; Lendvai, D.; Celli, M.; Viozzi, L.; Troiani, P.; Turri, E.; Giardini, O., Erythrocyte and plasma levels of glutamate and aspartate in children affected by migraine. Cephalalgia 1997,17 (6), 652-7.

[23] Schurks, M., Genetics of migraine in the age of genome-wide association studies. $J$ Headache Pain 2012,13 (1), 1-9.

[24] Burstein, R.; Noseda, R.; Borsook, D., Migraine: multiple processes, complex pathophysiology. J Neurosci 2015,35 (17), 6619-29.

[25] Kaube, H.; Herzog, J.; Kaufer, T.; Dichgans, M.; Diener, H. C., Aura in some patients with familial hemiplegic migraine can be stopped by intranasal ketamine. Neurology 2000,55 (1), 139-41.

[26] Baad-Hansen, L.; Cairns, B.; Ernberg, M.; Svensson, P., Effect of systemic monosodium glutamate (MSG) on headache and pericranial muscle sensitivity. Cephalalgia 2010,30 (1), 68-76.

[27] Shimada, A.; Baad-Hansen, L.; Castrillon, E.; Ghafouri, B.; Stensson, N.; Gerdle, B.; Ernberg, M.; Cairns, B.; Svensson, P., Differential effects of repetitive oral administration of monosodium glutamate on interstitial glutamate concentration and muscle pain sensitivity. Nutrition 2015,31 (2), 315-23.

[28] O'Brien, M.; Cairns, B. E., Monosodium glutamate alters the response properties of rat trigeminovascular neurons through activation of peripheral NMDA receptors. Neuroscience 2016,334, 236-244.

[29] Bohar, Z.; Toldi, J.; Fulop, F.; Vecsei, L., Changing the face of kynurenines and neurotoxicity: therapeutic considerations. Int J Mol Sci 2015,16 (5), 9772-93.

[30] Knyihar-Csillik, E.; Toldi, J.; Mihaly, A.; Krisztin-Peva, B.; Chadaide, Z.; Nemeth, H.; Fenyo, R.; Vecsei, L., Kynurenine in combination with probenecid mitigates the stimulation-induced increase of c-fos immunoreactivity of the rat caudal trigeminal nucleus in an experimental migraine model. $J$ Neural Transm (Vienna) 2007,114 (4), 417-21.

[31] Knyihar-Csillik, E.; Toldi, J.; Krisztin-Peva, B.; Chadaide, Z.; Nemeth, H.; Fenyo, R.; Vecsei, L., Prevention of electrical stimulation-induced increase of c-fos immunoreaction in the caudal trigeminal nucleus by kynurenine combined with probenecid. Neurosci Lett 2007,418 (2), 122-6.

[32] Vamos, E.; Pardutz, A.; Varga, H.; Bohar, Z.; Tajti, J.; Fulop, F.; Toldi, J.; Vecsei, L., l-kynurenine combined with probenecid and the novel synthetic kynurenic acid derivative attenuate nitroglycerin-induced nNOS in the rat caudal trigeminal nucleus. Neuropharmacology 2009,57 (4), 425-9.

[33] Vamos, E.; Fejes, A.; Koch, J.; Tajti, J.; Fulop, F.; Toldi, J.; Pardutz, A.; Vecsei, L., Kynurenate derivative attenuates the nitroglycerin-induced CamKIIalpha and CGRP expression changes. Headache 2010,50 (5), 834-43.

[34] Olah, G.; Heredi, J.; Menyhart, A.; Czinege, Z.; Nagy, D.; Fuzik, J.; Kocsis, K.; Knapp, L.; Krucso, E.; Gellert, L.; Kis, Z.; Farkas, T.; Fulop, F.; Pardutz, A.; Tajti, J.; Vecsei, L.; Toldi, J., Unexpected effects of peripherally administered kynurenic acid on cortical spreading depression and related blood-brain barrier permeability. Drug Des Devel Ther 2013,7, 981-7. 
[35] Chauvel, V.; Vamos, E.; Pardutz, A.; Vecsei, L.; Schoenen, J.; Multon, S., Effect of systemic kynurenine on cortical spreading depression and its modulation by sex hormones in rat. Exp Neurol 2012,236 (2), 207-14.

[36] Curto, M.; Lionetto, L.; Negro, A.; Capi, M.; Fazio, F.; Giamberardino, M. A.; Simmaco, M.; Nicoletti, F.; Martelletti, P., Altered kynurenine pathway metabolites in serum of chronic migraine patients. J Headache Pain 2015, 17 (1), 47.

[37] Vaudry, D.; Falluel-Morel, A.; Bourgault, S.; Basille, M.; Burel, D.; Wurtz, O.; Fournier, A.; Chow, B. K.; Hashimoto, H.; Galas, L.; Vaudry, H., Pituitary adenylate cyclaseactivating polypeptide and its receptors: 20 years after the discovery. Pharmacol Rev 2009,61 (3), 283-357.

[38] Tajti, J.; Uddman, R.; Moller, S.; Sundler, F.; Edvinsson, L., Messenger molecules and receptor mRNA in the human trigeminal ganglion. J Auton Nerv Syst 1999,76 (2-3), 176-83.

[39] Tajti, J.; Uddman, R.; Edvinsson, L., Neuropeptide localization in the "migraine generator" region of the human brainstem. Cephalalgia 2001,21 (2), 96-101.

[40] Schytz, H. W.; Birk, S.; Wienecke, T.; Kruuse, C.; Olesen, J.; Ashina, M., PACAP38 induces migraine-like attacks in patients with migraine without aura. Brain 2009,132 (Pt 1), 16-25.

[41] Amin, F. M.; Hougaard, A.; Schytz, H. W.; Asghar, M. S.; Lundholm, E.; Parvaiz, A. I.; de Koning, P. J.; Andersen, M. R.; Larsson, H. B.; Fahrenkrug, J.; Olesen, J.; Ashina, M., Investigation of the pathophysiological mechanisms of migraine attacks induced by pituitary adenylate cyclase-activating polypeptide-38. Brain 2014,137 (Pt 3), 779-94.

[42] Tuka, B.; Helyes, Z.; Markovics, A.; Bagoly, T.; Nemeth, J.; Mark, L.; Brubel, R.; Reglodi, D.; Pardutz, A.; Szolcsanyi, J.; Vecsei, L.; Tajti, J., Peripheral and central alterations of pituitary adenylate cyclase activating polypeptide-like immunoreactivity in the rat in response to activation of the trigeminovascular system. Peptides 2012,33 (2), 307-16.

[43] Markovics, A.; Kormos, V.; Gaszner, B.; Lashgarara, A.; Szoke, E.; Sandor, K.; Szabadfi, K.; Tuka, B.; Tajti, J.; Szolcsanyi, J.; Pinter, E.; Hashimoto, H.; Kun, J.; Reglodi, D.; Helyes, Z., Pituitary adenylate cyclase-activating polypeptide plays a key role in nitroglycerol-induced trigeminovascular activation in mice. Neurobiol Dis 2012,45 (1), 63344.

[44] Tuka, B.; Helyes, Z.; Markovics, A.; Bagoly, T.; Szolcsanyi, J.; Szabo, N.; Toth, E.; Kincses, Z. T.; Vecsei, L.; Tajti, J., Alterations in PACAP-38-like immunoreactivity in the plasma during ictal and interictal periods of migraine patients. Cephalalgia 2013,33 (13), $1085-95$.

[45] Hayaishi, O.; Rothberg, S.; Mehler, A. H.; Saito, Y., Studies on oxygenases; enzymatic formation of kynurenine from tryptophan. J Biol Chem 1957,229 (2), 889-96.

[46] Heyes, M. P.; Chen, C. Y.; Major, E. O.; Saito, K., Different kynurenine pathway enzymes limit quinolinic acid formation by various human cell types. Biochem $J$ 1997,326 (Pt 2), 351-6.

[47] Watanabe, Y.; Yoshida, R.; Sono, M.; Hayaishi, O., Immunohistochemical localization of indoleamine 2,3-dioxygenase in the argyrophilic cells of rabbit duodenum and thyroid gland. J Histochem Cytochem 1981,29 (5), 623-32.

[48] Reyes Ocampo, J.; Lugo Huitron, R.; Gonzalez-Esquivel, D.; Ugalde-Muniz, P.; Jimenez-Anguiano, A.; Pineda, B.; Pedraza-Chaverri, J.; Rios, C.; Perez de la Cruz, V., Kynurenines with neuroactive and redox properties: relevance to aging and brain diseases. Oxid Med Cell Longev 2014,2014, 646909.

[49] Gal, E. M.; Sherman, A. D., Synthesis and metabolism of L-kynurenine in rat brain. $J$ Neurochem 1978,30 (3), 607-13.

[50] Opitz, C. A.; Litzenburger, U. M.; Sahm, F.; Ott, M.; Tritschler, I.; Trump, S.; Schumacher, T.; Jestaedt, L.; Schrenk, D.; Weller, M.; Jugold, M.; Guillemin, G. J.; Miller, C. 
L.; Lutz, C.; Radlwimmer, B.; Lehmann, I.; von Deimling, A.; Wick, W.; Platten, M., An endogenous tumour-promoting ligand of the human aryl hydrocarbon receptor. Nature 2011,478 (7368), 197-203.

[51] Julliard, W.; Fechner, J. H.; Mezrich, J. D., The aryl hydrocarbon receptor meets immunology: friend or foe? A little of both. Front Immunol 2014,5, 458.

[52] Murray, I. A.; Patterson, A. D.; Perdew, G. H., Aryl hydrocarbon receptor ligands in cancer: friend and foe. Nat Rev Cancer 2014,14 (12), 801-14.

[53] Gaubert, S.; Bouchaut, M.; Brumas, V.; Berthon, G., Copper--ligand interactions and the physiological free radical processes. Part 3. Influence of histidine, salicylic acid and anthranilic acid on copper-driven Fenton chemistry in vitro. Free Radic Res 2000,32 (5), 45161.

[54] Schwarcz, R.; Pellicciari, R., Manipulation of brain kynurenines: glial targets, neuronal effects, and clinical opportunities. J Pharmacol Exp Ther 2002,303 (1), 1-10.

[55] Sahm, F.; Oezen, I.; Opitz, C. A.; Radlwimmer, B.; von Deimling, A.; Ahrendt, T.; Adams, S.; Bode, H. B.; Guillemin, G. J.; Wick, W.; Platten, M., The endogenous tryptophan metabolite and NAD + precursor quinolinic acid confers resistance of gliomas to oxidative stress. Cancer Res 2013,73 (11), 3225-34.

[56] Dykens, J. A.; Sullivan, S. G.; Stern, A., Oxidative reactivity of the tryptophan metabolites 3-hydroxyanthranilate, cinnabarinate, quinolinate and picolinate. Biochem Pharmacol 1987,36 (2), 211-7.

[57] Guidetti, P.; Schwarcz, R., 3-Hydroxykynurenine potentiates quinolinate but not NMDA toxicity in the rat striatum. Eur J Neurosci 1999,11 (11), 3857-63.

[58] Okuda, S.; Nishiyama, N.; Saito, H.; Katsuki, H., Hydrogen peroxide-mediated neuronal cell death induced by an endogenous neurotoxin, 3-hydroxykynurenine. Proc Natl Acad Sci U S A 1996,93 (22), 12553-8.

[59] Behan, W. M.; McDonald, M.; Darlington, L. G.; Stone, T. W., Oxidative stress as a mechanism for quinolinic acid-induced hippocampal damage: protection by melatonin and deprenyl. Br J Pharmacol 1999,128 (8), 1754-60.

[60] Rios, C.; Santamaria, A., Quinolinic acid is a potent lipid peroxidant in rat brain homogenates. Neurochem Res 1991,16 (10), 1139-43.

[61] Han, Q.; Cai, T.; Tagle, D. A.; Li, J., Structure, expression, and function of kynurenine aminotransferases in human and rodent brains. Cell Mol Life Sci 2010,67 (3), 353-68.

[62] Plant, N.; Kitchen, I.; Goldfarb, P. S.; Gibson, G. G., Developmental modulation of cysteine conjugate beta-lyase/glutamine transaminase $\mathrm{K} /$ kynurenine aminotransferase mRNA in rat brain. Eur J Drug Metab Pharmacokinet 1997,22 (4), 335-9.

[63] Guidetti, P.; Okuno, E.; Schwarcz, R., Characterization of rat brain kynurenine aminotransferases I and II. $J$ Neurosci Res 1997,50 (3), 457-65.

[64] Buchli, R.; Alberati-Giani, D.; Malherbe, P.; Kohler, C.; Broger, C.; Cesura, A. M., Cloning and functional expression of a soluble form of kynurenine/alpha-aminoadipate aminotransferase from rat kidney. $J$ Biol Chem 1995,270 (49), 29330-5.

[65] Smith, D. H.; Okiyama, K.; Thomas, M. J.; McIntosh, T. K., Effects of the excitatory amino acid receptor antagonists kynurenate and indole-2-carboxylic acid on behavioral and neurochemical outcome following experimental brain injury. $J$ Neurosci 1993,13 (12), 538392.

[66] Gigler, G.; Szenasi, G.; Simo, A.; Levay, G.; Harsing, L. G., Jr.; Sas, K.; Vecsei, L.; Toldi, J., Neuroprotective effect of L-kynurenine sulfate administered before focal cerebral ischemia in mice and global cerebral ischemia in gerbils. Eur J Pharmacol 2007,564 (1-3), 116-22. 
[67] Szalardy, L.; Zadori, D.; Toldi, J.; Fulop, F.; Klivenyi, P.; Vecsei, L., Manipulating kynurenic acid levels in the brain - on the edge between neuroprotection and cognitive dysfunction. Curr Top Med Chem 2012,12 (16), 1797-806.

[68] Prescott, C.; Weeks, A. M.; Staley, K. J.; Partin, K. M., Kynurenic acid has a dual action on AMPA receptor responses. Neurosci Lett 2006,402 (1-2), 108-12.

[69] Rozsa, E.; Robotka, H.; Vecsei, L.; Toldi, J., The Janus-face kynurenic acid. J Neural Transm (Vienna) 2008,115 (8), 1087-91.

[70] Hilmas, C.; Pereira, E. F.; Alkondon, M.; Rassoulpour, A.; Schwarcz, R.; Albuquerque, E. X., The brain metabolite kynurenic acid inhibits alpha7 nicotinic receptor activity and increases non-alpha7 nicotinic receptor expression: physiopathological implications. $J$ Neurosci 2001,21 (19), 7463-73.

[71] Dobelis, P.; Staley, K. J.; Cooper, D. C., Lack of modulation of nicotinic acetylcholine alpha-7 receptor currents by kynurenic acid in adult hippocampal interneurons. PLoS One 2012,7 (7), e41108.

[72] Moroni, F.; Russi, P.; Lombardi, G.; Beni, M.; Carla, V., Presence of kynurenic acid in the mammalian brain. J Neurochem 1988,51 (1), 177-80.

[73] Heyliger, S. O.; Goodman, C. B.; Ngong, J. M.; Soliman, K. F., The analgesic effects of tryptophan and its metabolites in the rat. Pharmacol Res 1998,38 (4), 243-50.

[74] Sas, K.; Robotka, H.; Rozsa, E.; Agoston, M.; Szenasi, G.; Gigler, G.; Marosi, M.; Kis, Z.; Farkas, T.; Vecsei, L.; Toldi, J., Kynurenine diminishes the ischemia-induced histological and electrophysiological deficits in the rat hippocampus. Neurobiol Dis 2008,32 (2), 302-8.

[75] Kemp, J. A.; Foster, A. C.; Leeson, P. D.; Priestley, T.; Tridgett, R.; Iversen, L. L.; Woodruff, G. N., 7-Chlorokynurenic acid is a selective antagonist at the glycine modulatory site of the N-methyl-D-aspartate receptor complex. Proc Natl Acad Sci U S A 1988,85 (17), 6547-50.

[76] Stone, T. W., Development and therapeutic potential of kynurenic acid and kynurenine derivatives for neuroprotection. Trends Pharmacol Sci 2000,21 (4), 149-54.

[77] Fulop, F.; Szatmari, I.; Vamos, E.; Zadori, D.; Toldi, J.; Vecsei, L., Syntheses, transformations and pharmaceutical applications of kynurenic acid derivatives. Curr Med Chem 2009,16 (36), 4828-42.

[78] Fejes-Szabo, A.; Bohar, Z.; Vamos, E.; Nagy-Grocz, G.; Tar, L.; Veres, G.; Zadori, D.; Szentirmai, M.; Tajti, J.; Szatmari, I.; Fulop, F.; Toldi, J.; Pardutz, A.; Vecsei, L., Pretreatment with new kynurenic acid amide dose-dependently prevents the nitroglycerineinduced neuronal activation and sensitization in cervical part of trigemino-cervical complex. $J$ Neural Transm (Vienna) 2014,121 (7), 725-38.

[79] Gregoire, L.; Rassoulpour, A.; Guidetti, P.; Samadi, P.; Bedard, P. J.; Izzo, E.; Schwarcz, R.; Di Paolo, T., Prolonged kynurenine 3-hydroxylase inhibition reduces development of levodopa-induced dyskinesias in parkinsonian monkeys. Behav Brain Res 2008,186 (2), 161-7.

[80] Amori, L.; Guidetti, P.; Pellicciari, R.; Kajii, Y.; Schwarcz, R., On the relationship between the two branches of the kynurenine pathway in the rat brain in vivo. $J$ Neurochem 2009,109 (2), 316-25.

[81] Speciale, C.; Wu, H. Q.; Cini, M.; Marconi, M.; Varasi, M.; Schwarcz, R., (R,S)-3,4dichlorobenzoylalanine (FCE 28833A) causes a large and persistent increase in brain kynurenic acid levels in rats. Eur J Pharmacol 1996,315 (3), 263-7.

[82] Rover, S.; Cesura, A. M.; Huguenin, P.; Kettler, R.; Szente, A., Synthesis and biochemical evaluation of $\mathrm{N}$-(4-phenylthiazol-2-yl)benzenesulfonamides as high-affinity inhibitors of kynurenine 3-hydroxylase. J Med Chem 1997,40 (26), 4378-85.

[83] Pardutz, A.; Fejes, A.; Bohar, Z.; Tar, L.; Toldi, J.; Vecsei, L., Kynurenines and headache. J Neural Transm (Vienna) 2012,119 (2), 285-96. 
[84] Fejes, A.; Pardutz, A.; Toldi, J.; Vecsei, L., Kynurenine metabolites and migraine: experimental studies and therapeutic perspectives. Curr Neuropharmacol 2011,9 (2), 376-87.

[85] Mecs, L.; Tuboly, G.; Nagy, E.; Benedek, G.; Horvath, G., The peripheral antinociceptive effects of endomorphin-1 and kynurenic acid in the rat inflamed joint model. Anesth Analg 2009,109 (4), 1297-304.

[86] Zhang, Y. Q.; Ji, G. C.; Wu, G. C.; Zhao, Z. Q., Kynurenic acid enhances electroacupuncture analgesia in normal and carrageenan-injected rats. Brain Res 2003,966 (2), 300-7.

[87] Nagy-Grocz, G.; Tar, L.; Bohar, Z.; Fejes-Szabo, A.; Laborc, K. F.; Spekker, E.; Vecsei, L.; Pardutz, A., The modulatory effect of anandamide on nitroglycerin-induced sensitization in the trigeminal system of the rat. Cephalalgia 2016,36 (9), 849-61.

[88] Knyihar-Csillik, E.; Chadaide, Z.; Okuno, E.; Krisztin-Peva, B.; Toldi, J.; Varga, C.; Molnar, A.; Csillik, B.; Vecsei, L., Kynurenine aminotransferase in the supratentorial dura mater of the rat: effect of stimulation of the trigeminal ganglion. Exp Neurol 2004,186 (2), 242-7.

[89] Bergerot, A.; Holland, P. R.; Akerman, S.; Bartsch, T.; Ahn, A. H.; MaassenVanDenBrink, A.; Reuter, U.; Tassorelli, C.; Schoenen, J.; Mitsikostas, D. D.; van den Maagdenberg, A. M.; Goadsby, P. J., Animal models of migraine: looking at the component parts of a complex disorder. Eur J Neurosci 2006,24 (6), 1517-34.

[90] Moskowitz, M. A.; Nozaki, K.; Kraig, R. P., Neocortical spreading depression provokes the expression of c-fos protein-like immunoreactivity within trigeminal nucleus caudalis via trigeminovascular mechanisms. J Neurosci 1993,13 (3), 1167-77.

[91] Lukacs, M.; Warfvinge, K.; Kruse, L. S.; Tajti, J.; Fulop, F.; Toldi, J.; Vecsei, L.; Edvinsson, L., KYNA analogue SZR72 modifies CFA-induced dural inflammation- regarding expression of pERK1/2 and IL-1 beta in the rat trigeminal ganglion. $J$ Headache Pain 2016,17 (1), 64.

[92] Clavelou, P.; Pajot, J.; Dallel, R.; Raboisson, P., Application of the formalin test to the study of orofacial pain in the rat. Neurosci Lett 1989,103 (3), 349-53.

[93] Fejes-Szabo, A.; Bohar, Z.; Nagy-Grocz, G.; Vamos, E.; Tar, L.; Podor, B.; Tajti, J.; Toldi, J.; Vecsei, L.; Pardutz, A., Effect of probenecid on the pain-related behaviour and morphological markers in orofacial formalin test of the rat. CNS Neurol Disord Drug Targets 2015, 14 (3), 350-9.

[94] Vecsei, L.; Miller, J.; MacGarvey, U.; Beal, M. F., Kynurenine and probenecid inhibit pentylenetetrazol- and NMDLA-induced seizures and increase kynurenic acid concentrations in the brain. Brain Res Bull 1992,28 (2), 233-8.

[95] Veres, G.; Fejes-Szabo, A.; Zadori, D.; Nagy-Grocz, G.; Laszlo, A. M.; Bajtai, A.; Mandity, I.; Szentirmai, M.; Bohar, Z.; Laborc, K.; Szatmari, I.; Fulop, F.; Vecsei, L.; Pardutz, A., A comparative assessment of two kynurenic acid analogs in the formalin model of trigeminal activation: a behavioral, immunohistochemical and pharmacokinetic study. $J$ Neural Transm (Vienna) 2016.

[96] Sato, K.; Kiyama, H.; Park, H. T.; Tohyama, M., AMPA, KA and NMDA receptors are expressed in the rat DRG neurones. Neuroreport 1993,4 (11), 1263-5.

[97] Shigemoto, R.; Ohishi, H.; Nakanishi, S.; Mizuno, N., Expression of the mRNA for the rat NMDA receptor (NMDAR1) in the sensory and autonomic ganglion neurons. Neurosci Lett 1992,144 (1-2), 229-32.

[98] Kinkelin, I.; Brocker, E. B.; Koltzenburg, M.; Carlton, S. M., Localization of ionotropic glutamate receptors in peripheral axons of human skin. Neurosci Lett 2000,283 (2), $149-52$ 
[99] Liu, H.; Wang, H.; Sheng, M.; Jan, L. Y.; Jan, Y. N.; Basbaum, A. I., Evidence for presynaptic N-methyl-D-aspartate autoreceptors in the spinal cord dorsal horn. Proc Natl Acad Sci U S A 1994,91 (18), 8383-7.

[100] Ohshiro, H.; Tonai-Kachi, H.; Ichikawa, K., GPR35 is a functional receptor in rat dorsal root ganglion neurons. Biochem Biophys Res Commun 2008,365 (2), 344-8.

[101] Song, X. J.; Zhao, Z. Q., Differential effects of NMDA and non-NMDA receptor antagonists on spinal cutaneous vs muscular nociception in the cat. Neuroreport 1993,4 (1), 17-20.

[102] Levine, E. S.; Jacobs, B. L., Neurochemical afferents controlling the activity of serotonergic neurons in the dorsal raphe nucleus: microiontophoretic studies in the awake cat. J Neurosci 1992,12 (10), 4037-44.

[103] Kalen, P.; Strecker, R. E.; Rosengren, E.; Bjorklund, A., Regulation of striatal serotonin release by the lateral habenula-dorsal raphe pathway in the rat as demonstrated by in vivo microdialysis: role of excitatory amino acids and GABA. Brain Res 1989,492 (1-2), 187202.

[104] Murphy, A. Z.; Behbehani, M. M., Electrophysiological characterization of the projection from the nucleus raphe magnus to the lateral reticular nucleus: possible role of an excitatory amino acid in synaptic activation. Brain Res 1993,606 (1), 68-78.

[105] Ennis, M.; Aston-Jones, G., Activation of locus coeruleus from nucleus paragigantocellularis: a new excitatory amino acid pathway in brain. $J$ Neurosci 1988,8 (10), 3644-57.

[106] Morgan, M. M.; Bobeck, E. N.; Ingram, S. L., Glutamate modulation of antinociception, but not tolerance, produced by morphine microinjection into the periaqueductal gray of the rat. Brain Res 2009,1295, 59-66.

[107] Curto, M.; Lionetto, L.; Negro, A.; Capi, M.; Perugino, F.; Fazio, F.; Giamberardino, M. A.; Simmaco, M.; Nicoletti, F.; Martelletti, P., Altered serum levels of kynurenine metabolites in patients affected by cluster headache. J Headache Pain 2015,17 (1), 27.

[108] Greco, R.; Gasperi, V.; Maccarrone, M.; Tassorelli, C., The endocannabinoid system and migraine. Exp Neurol 2010,224 (1), 85-91.

[109] Justinova, Z.; Mascia, P.; Wu, H. Q.; Secci, M. E.; Redhi, G. H.; Panlilio, L. V.; Scherma, M.; Barnes, C.; Parashos, A.; Zara, T.; Fratta, W.; Solinas, M.; Pistis, M.; Bergman, J.; Kangas, B. D.; Ferre, S.; Tanda, G.; Schwarcz, R.; Goldberg, S. R., Reducing cannabinoid abuse and preventing relapse by enhancing endogenous brain levels of kynurenic acid. Nat Neurosci 2013, 16 (11), 1652-61.

[110] Zador, F.; Samavati, R.; Szlavicz, E.; Tuka, B.; Bojnik, E.; Fulop, F.; Toldi, J.; Vecsei, L.; Borsodi, A., Inhibition of opioid receptor mediated G-protein activity after chronic administration of kynurenic acid and its derivative without direct binding to opioid receptors. CNS Neurol Disord Drug Targets 2014,13 (9), 1520-9.

[111] Rassoulpour, A.; Wu, H. Q.; Ferre, S.; Schwarcz, R., Nanomolar concentrations of kynurenic acid reduce extracellular dopamine levels in the striatum. $J$ Neurochem 2005,93 (3), 762-5.

[112] Amori, L.; Wu, H. Q.; Marinozzi, M.; Pellicciari, R.; Guidetti, P.; Schwarcz, R., Specific inhibition of kynurenate synthesis enhances extracellular dopamine levels in the rodent striatum. Neuroscience 2009,159 (1), 196-203.

[113] Shepard, P. D.; Joy, B.; Clerkin, L.; Schwarcz, R., Micromolar brain levels of kynurenic acid are associated with a disruption of auditory sensory gating in the rat. Neuropsychopharmacology 2003,28 (8), 1454-62.

[114] Chess, A. C.; Simoni, M. K.; Alling, T. E.; Bucci, D. J., Elevations of endogenous kynurenic acid produce spatial working memory deficits. Schizophr Bull 2007,33 (3), 797-804. 
[115] Chess, A. C.; Landers, A. M.; Bucci, D. J., L-kynurenine treatment alters contextual fear conditioning and context discrimination but not cue-specific fear conditioning. Behav Brain Res 2009,201 (2), 325-31.

[116] Wurtman, R. J., Daily rhythms in tyrosine transaminase and other hepatic enzymes that metabolize amino acids: mechanisms and possible consequences. Life Sci 1974,15 (5), 827-47.

[117] Schimke, R. T.; Doyle, D., Control of enzyme levels in animal tissues. Annu Rev Biochem 1970,39, 929-76.

[118] Mandi, Y.; Vecsei, L., The kynurenine system and immunoregulation. J Neural Transm (Vienna) 2012,119 (2), 197-209.

[119] Majewski, M.; Kozlowska, A.; Thoene, M.; Lepiarczyk, E.; Grzegorzewski, W. J., Overview of the role of vitamins and minerals on the kynurenine pathway in health and disease. J Physiol Pharmacol 2016,67 (1), 3-19.

[120] Holtz, P.; Palm, D., Pharmacological Aspects of Vitamin B6. Pharmacol Rev 1964,16, 113-78.

[121] Menon, S.; Nasir, B.; Avgan, N.; Ghassabian, S.; Oliver, C.; Lea, R.; Smith, M.; Griffiths, L., The effect of $1 \mathrm{mg}$ folic acid supplementation on clinical outcomes in female migraine with aura patients. J Headache Pain 2016,17 (1), 60.

[122] Baddiley, J., Pyridoxal derivatives in transamination. Nature 1952,170 (4330), 711-2.

[123] Metzler, D. E., Metal-binding by pyridoxal derivatives and possible relationships to tryptophan metabolism. Fed Proc 1961,20(3)Pt 2, 234-40.

[124] el-Sewedy, S. M.; Abdel-Tawab, G. A.; el-Zoghby, S. M.; Zeitoun, R.; Mostafa, M. H.; Shalaby, S. M., Studies with tryptophan metabolites in vitro. Effect of zinc, manganese, copper and cobalt ions on kynurenine hydrolase and kynurenine aminotransferase in normal mouse liver. Biochem Pharmacol 1974,23 (18), 2557-65.

[125] el-Sewedy, S. M.; Abdel-Tawab, G. A.; Abdel-Daim, M. H.; el-Sawy, M. F., Studies with tryptophan metabolites in vitro. V. Effect of the methanesulphonate derivative of hycanthone (etrenol) and lead acetate on kynureninase and kynurenine transaminase of normal mouse liver. Biochem Pharmacol 1972,21 (3), 379-90.

[126] Svajger, U.; Jeras, M., Anti-inflammatory effects of resveratrol and its potential use in therapy of immune-mediated diseases. Int Rev Immunol 2012,31 (3), 202-22.

[127] Bishayee, A., Cancer prevention and treatment with resveratrol: from rodent studies to clinical trials. Cancer Prev Res (Phila) 2009,2 (5), 409-18.

[128] Gualdoni, G. A.; Fuchs, D.; Zlabinger, G. J.; Gostner, J. M., Resveratrol intake enhances indoleamine-2,3-dioxygenase activity in humans. Pharmacol Rep 2016,68 (5), 1065-1068.

[129] Krymchantowski, A. V.; da Cunha Jevoux, C., Wine and headache. Headache 2014,54 (6), 967-75.

[130] Arimura, A., PACAP: the road to discovery. Peptides 2007,28 (9), 1617-9.

[131] Miyata, A.; Arimura, A.; Dahl, R. R.; Minamino, N.; Uehara, A.; Jiang, L.; Culler, M. D.; Coy, D. H., Isolation of a novel 38 residue-hypothalamic polypeptide which stimulates adenylate cyclase in pituitary cells. Biochem Biophys Res Commun 1989,164 (1), 567-74.

[132] Kimura, C.; Ohkubo, S.; Ogi, K.; Hosoya, M.; Itoh, Y.; Onda, H.; Miyata, A.; Jiang, L.; Dahl, R. R.; Stibbs, H. H.; et al., A novel peptide which stimulates adenylate cyclase: molecular cloning and characterization of the ovine and human cDNAs. Biochem Biophys Res Commun 1990,166 (1), 81-9.

[133] Bourgault, S.; Vaudry, D.; Botia, B.; Couvineau, A.; Laburthe, M.; Vaudry, H.; Fournier, A., Novel stable PACAP analogs with potent activity towards the PAC1 receptor. Peptides 2008,29 (6), 919-32. 
[134] Uddman, R.; Tajti, J.; Hou, M.; Sundler, F.; Edvinsson, L., Neuropeptide expression in the human trigeminal nucleus caudalis and in the cervical spinal cord $\mathrm{C} 1$ and $\mathrm{C} 2$. Cephalalgia 2002,22 (2), 112-6.

[135] Palkovits, M.; Somogyvari-Vigh, A.; Arimura, A., Concentrations of pituitary adenylate cyclase activating polypeptide (PACAP) in human brain nuclei. Brain Res 1995,699 (1), 116-20.

[136] Masuo, Y.; Ohtaki, T.; Masuda, Y.; Tsuda, M.; Fujino, M., Binding sites for pituitary adenylate cyclase activating polypeptide (PACAP): comparison with vasoactive intestinal polypeptide (VIP) binding site localization in rat brain sections. Brain Res 1992,575 (1), 11323.

[137] Reglodi, D.; Kiss, P.; Horvath, G.; Lubics, A.; Laszlo, E.; Tamas, A.; Racz, B.; Szakaly, P., Effects of pituitary adenylate cyclase activating polypeptide in the urinary system, with special emphasis on its protective effects in the kidney. Neuropeptides 2012,46 (2), 6170 .

[138] Fahrenkrug, J.; Hannibal, J., Localisation of the neuropeptide PACAP and its receptors in the rat parathyroid and thyroid glands. Gen Comp Endocrinol 2011,171 (1), 105-13.

[139] Koves, K.; Kantor, O.; Scammell, J. G.; Arimura, A., PACAP colocalizes with luteinizing and follicle-stimulating hormone immunoreactivities in the anterior lobe of the pituitary gland. Peptides 1998,19 (6), 1069-72.

[140] Borzsei, R.; Mark, L.; Tamas, A.; Bagoly, T.; Bay, C.; Csanaky, K.; Banki, E.; Kiss, P.; Vaczy, A.; Horvath, G.; Nemeth, J.; Szauer, E.; Helyes, Z.; Reglodi, D., Presence of pituitary adenylate cyclase activating polypeptide-38 in human plasma and milk. Eur $J$ Endocrinol 2009,160 (4), 561-5.

[141] Moody, T. W.; Ito, T.; Osefo, N.; Jensen, R. T., VIP and PACAP: recent insights into their functions/roles in physiology and disease from molecular and genetic studies. Curr Opin Endocrinol Diabetes Obes 2011,18 (1), 61-7.

[142] Sherwood, N. M.; Krueckl, S. L.; McRory, J. E., The origin and function of the pituitary adenylate cyclase-activating polypeptide (PACAP)/glucagon superfamily. Endocr Rev 2000,21 (6), 619-70.

[143] Koves, K.; Arimura, A.; Somogyvari-Vigh, A.; Vigh, S.; Miller, J., Immunohistochemical demonstration of a novel hypothalamic peptide, pituitary adenylate cyclase-activating polypeptide, in the ovine hypothalamus. Endocrinology 1990,127 (1), 26471 .

[144] Hashimoto, H.; Shintani, N.; Tanida, M.; Hayata, A.; Hashimoto, R.; Baba, A., PACAP is implicated in the stress axes. Curr Pharm Des 2011,17 (10), 985-9.

[145] Seaborn, T.; Masmoudi-Kouli, O.; Fournier, A.; Vaudry, H.; Vaudry, D., Protective effects of pituitary adenylate cyclase-activating polypeptide (PACAP) against apoptosis. Curr Pharm Des 2011,17 (3), 204-14.

[146] Ohtsuka, M.; Fukumitsu, H.; Furukawa, S., PACAP decides neuronal laminar fate via PKA signaling in the developing cerebral cortex. Biochem Biophys Res Commun 2008,369 (4), 1144-9.

[147] Watanabe, J.; Nakamachi, T.; Matsuno, R.; Hayashi, D.; Nakamura, M.; Kikuyama, S.; Nakajo, S.; Shioda, S., Localization, characterization and function of pituitary adenylate cyclase-activating polypeptide during brain development. Peptides 2007,28 (9), 1713-9.

[148] Reglodi, D.; Kiss, P.; Lubics, A.; Tamas, A., Review on the protective effects of PACAP in models of neurodegenerative diseases in vitro and in vivo. Curr Pharm Des 2011,17 (10), 962-72.

[149] Ferencz, A.; Weber, G.; Helyes, Z.; Hashimoto, H.; Baba, A.; Reglodi, D., Presence of endogenous PACAP-38 ameliorated intestinal cold preservation tissue injury. J Mol Neurosci 2010,42 (3), 428-34. 
[150] Ishizuka, Y.; Kashimoto, K.; Mochizuki, T.; Sato, K.; Ohshima, K.; Yanaihara, N., Cardiovascular and respiratory actions of pituitary adenylate cyclase-activating polypeptides. Regul Pept 1992,40 (1), 29-39.

[151] Racz, B.; Reglodi, D.; Horvath, G.; Szigeti, A.; Balatonyi, B.; Roth, E.; Weber, G.; Alotti, N.; Toth, G.; Gasz, B., Protective effect of PACAP against doxorubicin-induced cell death in cardiomyocyte culture. $J$ Mol Neurosci 2010,42 (3), 419-27.

[152] Warren, J. B.; Cockcroft, J. R.; Larkin, S. W.; Kajekar, R.; Macrae, A.; Ghatei, M. A.; Bloom, S. R., Pituitary adenylate cyclase activating polypeptide is a potent vasodilator in humans. J Cardiovasc Pharmacol 1992,20 (1), 83-7.

[153] Barberi, M.; Muciaccia, B.; Morelli, M. B.; Stefanini, M.; Cecconi, S.; Canipari, R., Expression localisation and functional activity of pituitary adenylate cyclase-activating polypeptide, vasoactive intestinal polypeptide and their receptors in mouse ovary. Reproduction 2007,134 (2), 281-92.

[154] Lacombe, A.; Lelievre, V.; Roselli, C. E.; Salameh, W.; Lue, Y. H.; Lawson, G.; Muller, J. M.; Waschek, J. A.; Vilain, E., Delayed testicular aging in pituitary adenylate cyclase-activating peptide (PACAP) null mice. Proc Natl Acad Sci U S A 2006,103 (10), 3793-8.

[155] Elekes, K.; Sandor, K.; Moricz, A.; Kereskai, L.; Kemeny, A.; Szoke, E.; Perkecz, A.; Reglodi, D.; Hashimoto, H.; Pinter, E.; Szolcsanyi, J.; Helyes, Z., Pituitary adenylate cyclaseactivating polypeptide plays an anti-inflammatory role in endotoxin-induced airway inflammation: in vivo study with gene-deleted mice. Peptides 2011,32 (7), 1439-46.

[156] Schytz, H. W.; Olesen, J.; Ashina, M., The PACAP receptor: a novel target for migraine treatment. Neurotherapeutics 2010,7 (2), 191-6.

[157] Laburthe, M.; Couvineau, A.; Tan, V., Class II G protein-coupled receptors for VIP and PACAP: structure, models of activation and pharmacology. Peptides 2007,28 (9), 1631-9. [158] Harmar, A. J.; Fahrenkrug, J.; Gozes, I.; Laburthe, M.; May, V.; Pisegna, J. R.; Vaudry, D.; Vaudry, H.; Waschek, J. A.; Said, S. I., Pharmacology and functions of receptors for vasoactive intestinal peptide and pituitary adenylate cyclase-activating polypeptide: IUPHAR review 1. Br J Pharmacol 2012,166 (1), 4-17.

[159] Erdling, A.; Sheykhzade, M.; Maddahi, A.; Bari, F.; Edvinsson, L., VIP/PACAP receptors in cerebral arteries of rat: characterization, localization and relation to intracellular calcium. Neuropeptides 2013,47 (2), 85-92.

[160] Jansen-Olesen, I.; Baun, M.; Amrutkar, D. V.; Ramachandran, R.; Christophersen, D. V.; Olesen, J., PACAP-38 but not VIP induces release of CGRP from trigeminal nucleus caudalis via a receptor distinct from the PAC1 receptor. Neuropeptides 2014,48 (2), 53-64.

[161] Akerman, S.; Goadsby, P. J., Neuronal PAC1 receptors mediate delayed activation and sensitization of trigeminocervical neurons: Relevance to migraine. Sci Transl Med 2015,7 (308), 308ra157.

[162] Chan, K. Y.; Baun, M.; de Vries, R.; van den Bogaerdt, A. J.; Dirven, C. M.; Danser, A. H.; Jansen-Olesen, I.; Olesen, J.; Villalon, C. M.; MaassenVanDenBrink, A.; Gupta, S., Pharmacological characterization of VIP and PACAP receptors in the human meningeal and coronary artery. Cephalalgia 2011,31 (2), 181-9.

[163] Gupta, S.; Bhatt, D. K.; Boni, L. J.; Olesen, J., Improvement of the closed cranial window model in rats by intracarotid infusion of signalling molecules implicated in migraine. Cephalalgia 2010,30 (1), 27-36.

[164] Helyes, Z.; Pozsgai, G.; Borzsei, R.; Nemeth, J.; Bagoly, T.; Mark, L.; Pinter, E.; Toth, G.; Elekes, K.; Szolcsanyi, J.; Reglodi, D., Inhibitory effect of PACAP-38 on acute neurogenic and non-neurogenic inflammatory processes in the rat. Peptides 2007,28 (9), $1847-55$. 
[165] Narita, M.; Dun, S. L.; Dun, N. J.; Tseng, L. F., Hyperalgesia induced by pituitary adenylate cyclase-activating polypeptide in the mouse spinal cord. Eur J Pharmacol 1996,311 (2-3), 121-6.

[166] Nemeth, J.; Reglodi, D.; Pozsgai, G.; Szabo, A.; Elekes, K.; Pinter, E.; Szolcsanyi, J.; Helyes, Z., Effect of pituitary adenylate cyclase activating polypeptide-38 on sensory neuropeptide release and neurogenic inflammation in rats and mice. Neuroscience 2006,143 (1), 223-30.

[167] Sandor, K.; Bolcskei, K.; McDougall, J. J.; Schuelert, N.; Reglodi, D.; Elekes, K.; Petho, G.; Pinter, E.; Szolcsanyi, J.; Helyes, Z., Divergent peripheral effects of pituitary adenylate cyclase-activating polypeptide-38 on nociception in rats and mice. Pain 2009,141 (1-2), 143-50.

[168] Sandor, K.; Kormos, V.; Botz, B.; Imreh, A.; Bolcskei, K.; Gaszner, B.; Markovics, A.; Szolcsanyi, J.; Shintani, N.; Hashimoto, H.; Baba, A.; Reglodi, D.; Helyes, Z., Impaired nocifensive behaviours and mechanical hyperalgesia, but enhanced thermal allodynia in pituitary adenylate cyclase-activating polypeptide deficient mice. Neuropeptides 2010,44 (5), $363-71$.

[169] Zhang, Y.; Danielsen, N.; Sundler, F.; Mulder, H., Pituitary adenylate cyclaseactivating peptide is upregulated in sensory neurons by inflammation. Neuroreport 1998,9 (12), 2833-6.

[170] Zhang, Y.; Malmberg, A. B.; Sjolund, B.; Yaksh, T. L., The effect of pituitary adenylate cyclase activating peptide (PACAP) on the nociceptive formalin test. Neurosci Lett 1996,207 (3), 187-90.

[171] Baeres, F. M.; Moller, M., Origin of PACAP-immunoreactive nerve fibers innervating the subarachnoidal blood vessels of the rat brain. J Cereb Blood Flow Metab 2004,24 (6), 628-35.

[172] Nielsen, H. S.; Hannibal, J.; Fahrenkrug, J., Embryonic expression of pituitary adenylate cyclase-activating polypeptide in sensory and autonomic ganglia and in spinal cord of the rat. J Comp Neurol 1998,394 (4), 403-15.

[173] Chaudhary, P.; Baumann, T. K., Expression of VPAC2 receptor and PAC1 receptor splice variants in the trigeminal ganglion of the adult rat. Brain Res Mol Brain Res 2002,104 (2), 137-42.

[174] Saghy, E.; Payrits, M.; Helyes, Z.; Reglodi, D.; Banki, E.; Toth, G.; Couvineau, A.; Szoke, E., Stimulatory effect of pituitary adenylate cyclase-activating polypeptide 6-38, M65 and vasoactive intestinal polypeptide 6-28 on trigeminal sensory neurons. Neuroscience 2015,308, 144-56.

[175] Hou, M.; Uddman, R.; Tajti, J.; Edvinsson, L., Nociceptin immunoreactivity and receptor mRNA in the human trigeminal ganglion. Brain Res 2003,964 (2), 179-86.

[176] Uddman, R.; Tajti, J.; Moller, S.; Sundler, F.; Edvinsson, L., Neuronal messengers and peptide receptors in the human sphenopalatine and otic ganglia. Brain Res 1999,826 (2), 1939.

[177] Csati, A.; Tajti, J.; Kuris, A.; Tuka, B.; Edvinsson, L.; Warfvinge, K., Distribution of vasoactive intestinal peptide, pituitary adenylate cyclase-activating peptide, nitric oxide synthase, and their receptors in human and rat sphenopalatine ganglion. Neuroscience 2012,202, 158-68.

[178] Steinberg, A.; Frederiksen, S. D.; Blixt, F. W.; Warfvinge, K.; Edvinsson, L., Expression of messenger molecules and receptors in rat and human sphenopalatine ganglion indicating therapeutic targets. $J$ Headache Pain 2016,17 (1), 78.

[179] Mabuchi, T.; Shintani, N.; Matsumura, S.; Okuda-Ashitaka, E.; Hashimoto, H.; Muratani, T.; Minami, T.; Baba, A.; Ito, S., Pituitary adenylate cyclase-activating polypeptide 
is required for the development of spinal sensitization and induction of neuropathic pain. $J$ Neurosci 2004,24 (33), 7283-91.

[180] Eftekhari, S.; Salvatore, C. A.; Johansson, S.; Chen, T. B.; Zeng, Z.; Edvinsson, L., Localization of CGRP, CGRP receptor, PACAP and glutamate in trigeminal ganglion. Relation to the blood-brain barrier. Brain Res 2015,1600, 93-109.

[181] Olesen, J.; Iversen, H. K.; Thomsen, L. L., Nitric oxide supersensitivity: a possible molecular mechanism of migraine pain. Neuroreport 1993,4 (8), 1027-30.

[182] Sicuteri, F.; Del Bene, E.; Poggioni, M.; Bonazzi, A., Unmasking latent dysnociception in healthy subjects. Headache 1987,27 (4), 180-5.

[183] Baun, M.; Pedersen, M. H.; Olesen, J.; Jansen-Olesen, I., Dural mast cell degranulation is a putative mechanism for headache induced by PACAP-38. Cephalalgia 2012,32 (4), 337-45.

[184] Tajti, J.; Tuka, B.; Botz, B.; Helyes, Z.; Vecsei, L., Role of pituitary adenylate cyclase-activating polypeptide in nociception and migraine. CNS Neurol Disord Drug Targets 2015, 14 (4), 540-53.

[185] Bhatt, D. K.; Gupta, S.; Olesen, J.; Jansen-Olesen, I., PACAP-38 infusion causes sustained vasodilation of the middle meningeal artery in the rat: possible involvement of mast cells. Cephalalgia 2014,34 (11), 877-86.

[186] Mori, T.; Kawashima, T.; Beppu, Y.; Takagi, K., Histamine release induced by pituitary adenylate cyclase activating polypeptide from rat peritoneal mast cells. Arzneimittelforschung 1994,44 (9), 1044-6.

[187] Odum, L.; Petersen, L. J.; Skov, P. S.; Ebskov, L. B., Pituitary adenylate cyclase activating polypeptide (PACAP) is localized in human dermal neurons and causes histamine release from skin mast cells. Inflamm Res 1998,47 (12), 488-92.

[188] Delgado, M.; Ganea, D., Vasoactive intestinal peptide: a neuropeptide with pleiotropic immune functions. Amino Acids 2013,45 (1), 25-39.

[189] Kaiser, E. A.; Russo, A. F., CGRP and migraine: could PACAP play a role too? Neuropeptides 2013,47 (6), 451-61.

[190] Tajti, J.; Szok, D.; Majlath, Z.; Tuka, B.; Csati, A.; Vecsei, L., Migraine and neuropeptides. Neuropeptides 2015,52, 19-30.

[191] Tuka, B.; Szabo, N.; Toth, E.; Kincses, Z. T.; Pardutz, A.; Szok, D.; Kortesi, T.; Bagoly, T.; Helyes, Z.; Edvinsson, L.; Vecsei, L.; Tajti, J., Release of PACAP-38 in episodic cluster headache patients - an exploratory study. J Headache Pain 2016,17 (1), 69.

[192] Han, X.; Dong, Z.; Hou, L.; Wan, D.; Chen, M.; Tang, W.; Yu, S., Interictal plasma pituitary adenylate cyclase-activating polypeptide levels are decreased in migraineurs but remain unchanged in patients with tension-type headache. Clin Chim Acta 2015,450, 151-4.

[193] Hou, L.; Wan, D.; Dong, Z.; Tang, W.; Han, X.; Li, L.; Yang, F.; Yu, S., Pituitary adenylate cyclase-activating polypeptide expression in peripheral blood mononuclear cells of migraineurs. Cell Biosci 2016,6, 40.

[194] Zagami, A. S.; Edvinsson, L.; Goadsby, P. J., Pituitary adenylate cyclase activating polypeptide and migraine. Ann Clin Transl Neurol 2014,1 (12), 1036-40.

[195] Guo, S.; Vollesen, A. L.; Hansen, Y. B.; Frandsen, E.; Andersen, M. R.; Amin, F. M.; Fahrenkrug, J.; Olesen, J.; Ashina, M., Part II: Biochemical changes after pituitary adenylate cyclase-activating polypeptide-38 infusion in migraine patients. Cephalalgia 2016.

[196] Guo, S.; Vollesen, A. L.; Hansen, R. D.; Esserlind, A. L.; Amin, F. M.; Christensen, A. F.; Olesen, J.; Ashina, M., Part I: Pituitary adenylate cyclase-activating polypeptide-38 induced migraine-like attacks in patients with and without familial aggregation of migraine. Cephalalgia 2016. 
[197] Amin, F. M.; Hougaard, A.; Magon, S.; Asghar, M. S.; Ahmad, N. N.; Rostrup, E.; Sprenger, T.; Ashina, M., Change in brain network connectivity during PACAP38-induced migraine attacks: A resting-state functional MRI study. Neurology 2016,86 (2), 180-7.

[198] Tfelt-Hansen, P. C., PACAP-induced migraine: a possible CNS effect? Brain 2014,137 (Pt 11), e304.

[199] Edvinsson, L., PACAP and its receptors in migraine pathophysiology: Commentary on Walker et al., Br J Pharmacol 171: 1521-1533. Br J Pharmacol 2015,172 (19), 4782-4.

[200] Walker, C. S.; Sundrum, T.; Hay, D. L., PACAP receptor pharmacology and agonist bias: analysis in primary neurons and glia from the trigeminal ganglia and transfected cells. $\mathrm{Br}$ $J$ Pharmacol 2014,171 (6), 1521-33.

[201] Tajti, J.; Csati, A.; Vecsei, L., Novel strategies for the treatment of migraine attacks via the CGRP, serotonin, dopamine, PAC1, and NMDA receptors. Expert Opin Drug Metab Toxicol 2014,10 (11), 1509-20.

[202] Aurora, S. K.; Ahmad, B. K.; Welch, K. M.; Bhardhwaj, P.; Ramadan, N. M., Transcranial magnetic stimulation confirms hyperexcitability of occipital cortex in migraine. Neurology 1998,50 (4), 1111-4.

[203] Ferrari, M. D.; Odink, J.; Bos, K. D.; Malessy, M. J.; Bruyn, G. W., Neuroexcitatory plasma amino acids are elevated in migraine. Neurology 1990,40 (10), 1582-6.

[204] D'Andrea, G.; Cananzi, A. R.; Joseph, R.; Morra, M.; Zamberlan, F.; Ferro Milone, F.; Grunfeld, S.; Welch, K. M., Platelet glycine, glutamate and aspartate in primary headache. Cephalalgia 1991,11 (4), 197-200.

[205] Gawel, M.; Connolly, J. F.; Rose, F. C., Migraine patients exhibit abnormalities in the visual evoked potential. Headache 1983, 23 (2), 49-52.

[206] Schmidt, S. D.; Myskiw, J. C.; Furini, C. R.; Schmidt, B. E.; Cavalcante, L. E.; Izquierdo, I., PACAP modulates the consolidation and extinction of the contextual fear conditioning through NMDA receptors. Neurobiol Learn Mem 2015,118, 120-4.

[207] Resch, J. M.; Maunze, B.; Phillips, K. A.; Choi, S., Inhibition of food intake by PACAP in the hypothalamic ventromedial nuclei is mediated by NMDA receptors. Physiol Behav 2014,133, 230-5.

[208] Toda, A. M.; Huganir, R. L., Regulation of AMPA receptor phosphorylation by the neuropeptide PACAP38. Proc Natl Acad Sci U S A 2015,112 (21), 6712-7.

[209] Lauritsen, C.; Mazuera, S.; Lipton, R. B.; Ashina, S., Intravenous ketamine for subacute treatment of refractory chronic migraine: a case series. J Headache Pain 2016,17 (1), 106.

[210] Noruzzadeh, R.; Modabbernia, A.; Aghamollaii, V.; Ghaffarpour, M.; Harirchian, M. H.; Salahi, S.; Nikbakht, N.; Noruzi, N.; Tafakhori, A., Memantine for Prophylactic Treatment of Migraine Without Aura: A Randomized Double-Blind Placebo-Controlled Study. Headache 2016,56 (1), 95-103.

[211] Gomez-Mancilla, B.; Brand, R.; Jurgens, T. P.; Gobel, H.; Sommer, C.; Straube, A.; Evers, S.; Sommer, M.; Campos, V.; Kalkman, H. O.; Hariry, S.; Pezous, N.; Johns, D.; Diener, H. C.; Group, B. G. G. S., Randomized, multicenter trial to assess the efficacy, safety and tolerability of a single dose of a novel AMPA receptor antagonist BGG492 for the treatment of acute migraine attacks. Cephalalgia 2014,34 (2), 103-13.

[212] Sang, C. N.; Ramadan, N. M.; Wallihan, R. G.; Chappell, A. S.; Freitag, F. G.; Smith, T. R.; Silberstein, S. D.; Johnson, K. W.; Phebus, L. A.; Bleakman, D.; Ornstein, P. L.; Arnold, B.; Tepper, S. J.; Vandenhende, F., LY293558, a novel AMPA/GluR5 antagonist, is efficacious and well-tolerated in acute migraine. Cephalalgia 2004,24 (7), 596-602.

[213] Waung, M. W.; Akerman, S.; Wakefield, M.; Keywood, C.; Goadsby, P. J., Metabotropic glutamate receptor 5: a target for migraine therapy. Ann Clin Transl Neurol 2016,3 (8), 560-71. 


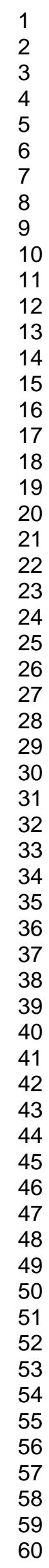

https://mc04.manuscriptcentral.com/crmc 


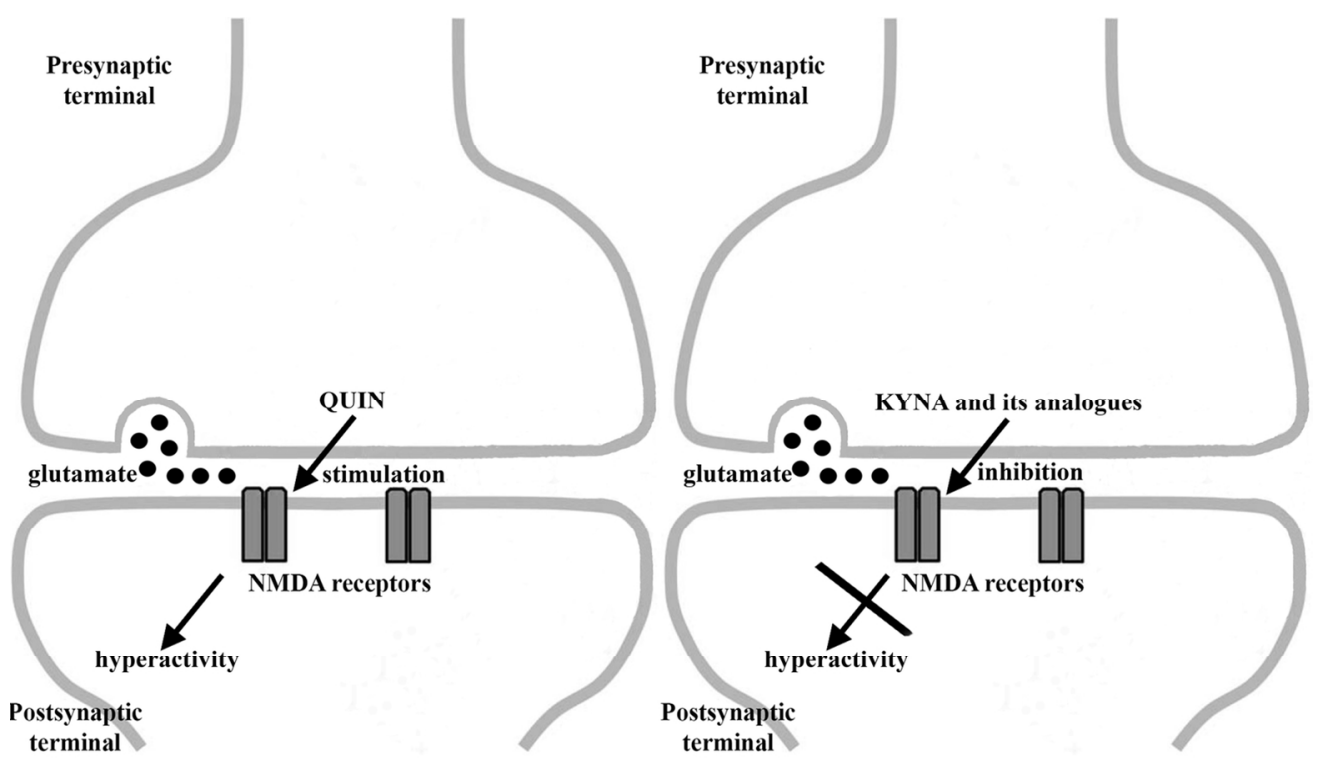

KYNA and its analogues are able to inhibit the glutamate-induced hyperexcitability, which has a relevant role in the pathomechanism of migraine.

$$
127 \times 75 \mathrm{~mm}(300 \times 300 \mathrm{DPI})
$$




\section{PACAP-27}

His-Ser-Asp-Gly-Ile-Phe-Thr-Asp-Ser-Tyr-SerArg-Tyr-Arg-Lys-Gln-Met-Ala-Val-Lys-LysTyr-Leu-Ala-Ala-Val-Leu- $\mathrm{NH}_{2}$

\section{PACAP-38}

His-Ser-Asp-Gly-Ile-Phe-Thr-Asp-Ser-Tyr-SerArg-Tyr-Arg-Lys-Gln-Met-Ala-Val-Lys-LysTyr-Leu-Ala-Ala-Val-Leu-Gly-Lys-Arg-Tyr-

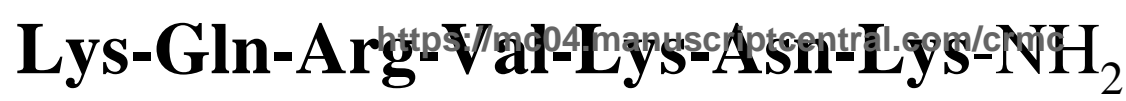




\section{Current Medicinal Chemistry}

1

2

3

4

5

6

7

8

9

10

11

12

13

14TRIG

15

16

17

18

19

20

21

22

23

24

25

26

27

28

29

30
DURA MATER PACAP, PAC $1, \mathrm{VPAC}_{1}, \mathrm{VPAC}_{2}$

CORTEX PACAP, $\mathrm{PAC}_{1}, \mathrm{VPAC}_{1}, \mathrm{VPAC}_{2}$ 


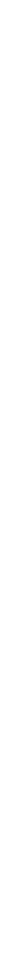

